\title{
Can Cognitive Capital Sustain Customer Satisfaction? The Mediating Effects of Employee Self-Efficacy
}

\author{
Mansour Abdullah Alyahya ${ }^{1}\left(\mathbb{D}\right.$, Elsayed Mohamed ${ }^{2}$, Raphaël Akamavi ${ }^{3}$, \\ Ibrahim A. Elshaer 1,4 (D) and Alaa M. S. Azzaz 5,6,* \\ 1 Management Department, College of Business Administration, King Faisal University, Al-Hassa 31982, \\ Saudi Arabia; malyahya@kfu.edu.sa (M.A.A.); ielshaer@kfu.edu.sa (I.A.E.) \\ 2 College of Economics and Administrative Sciences, Imam Mohammad Ibn Saud Islamic University, \\ Riyadh 11432, Saudi Arabia; esmohammed@imamu.edu.sa \\ 3 Department of Marketing, Birmingham Business School, University of Birmingham, Birmingham B15 2TY, \\ UK; r.k.akamavi@bham.ac.uk \\ 4 Hotel Studies Department, Faculty of Tourism and Hotels, Suez Canal University, Ismailia 41522, Egypt \\ 5 Department of Tourism and Hospitality, Arts College, King Faisal University, Al-Ahsa 380, Saudi Arabia \\ 6 Tourism Studies Department, Faculty of Tourism and Hotels, Suez Canal University, Ismailia 41522, Egypt \\ * Correspondence: aazazz@kfu.edu.sa
}

Received: 20 November 2020; Accepted: 11 December 2020; Published: 14 December 2020

\begin{abstract}
Despite the important role of cognitive capital as a facet of social capital, there is little empirical work examining the causal effect of cognitive capital dimensions on sustaining customer satisfaction. Thus, there is a need to investigate the relationship between these constructs via employee self-efficacy. Our proposed hypothetical framework is tested in the tourism industry sector employing a quantitative research method. Drawing from social capital and social cognitive theories, we generated items from a piloted questionnaire which was administered to 600 top and middle managers in hotels and travel agents using drop and collect methods. We test our hypothetical model using SEM techniques with 490 usable cases. The survey results indicate that cognitive capital dimensions have direct and indirect relationships with sustained customer satisfaction. In addition, employee self-efficacy mediates between exogenous constructs and the endogenous construct. Surprisingly, these two exogenous constructs: shared norms and shared values do directly influence shared goals and enhance employee self-efficacy. Additionally, shared goals enhance employee efficacy which subsequently leads to sustained customer satisfaction. These findings shed light on the impact of intra-firm social interactions on customer experience in hotels and travel agents. Managers should use cognitive capital to improve the level of service employee self-efficacy and subsequently sustain customer satisfaction. The paper outlines theoretical and managerial implications and addresses possible directions for further research.
\end{abstract}

Keywords: cognitive capital; employee self-efficacy; shared goals; shared norms; shared values; sustained customer satisfaction

\section{Introduction}

Generally speaking, maintaining a consumer relationship is based on sustaining customer satisfaction, which is determined by various factors including service quality, service performance, employee performance, service failure recovery, customer expectations [1-7]. Ref. [8] note "as the growth of services continues and world markets become increasingly competitive, the importance of customer satisfaction will also increase". Their viewpoint is still relevant to service sectors across the worldwide business milieu. As considered by Fornell [9], sustaining customer satisfaction as a "new economic indicator". 
Cognitive capital refers to an individual member's perception of the degree in which his/her team members share similar task- and team-related knowledge, values, philosophies, and problem-solving approaches [10]. Several scholars reveal that built up cognitive capital within any organisation over the years is influenced by social norms and values and managerial shared approaches [10-13]. Consequently, it molds and instills the realm of employee behaviours, and propels organisational practices [14-17].

According to the literature, cognitive capital entails three interrelated dimensions; shared values, shared norms, and shared goals. Shared values and norms represent the main streams for creating common goals among network members [18-23]. For example, Ref. [24] points out that achieving a shared goal is related to employees' values and norms. Moreover, Ref. [25] notes that "cultural value systems, cultural norms, and beliefs are prescribed by a collective establishment such as religion or society". In fact, cognitive capital is shaped by practices, ethical and moral obligations which act as a custodian compass for Egyptian services providers [26-28]. The adjustment to this set of hidden and unwritten rules, societal norms, and national/tribal culture (Thaqafa) is just as central to the transmission of cultural values as embedded elements of cognitive capital [29-32].

Cognitive capital is perceived to enable employees to increase social interactions within their organisations, perform well in the workplace, and help them in achieving organisational goals $[10,33]$. However, empirical support for this assumption is deemed difficult due to confusion in the composition of various components of cognitive capital [34]. Cognitive capital is a multidimensional concept, and empirical studies do not fully agree with their component assessments [22,23,35-38]. For instance, studies by Ref. [25,35,39] have focused on the contribution of common values, others have investigated the role of shared norms $[23,25,40]$ whereas others have examined the contributions of shared goals or vision [38,41,42]. All of these studies have been criticized for their weak and selective effects of cognitive capital. Such criticisms reveal the problem in the fragmentary examination of cognitive capital in different studies, especially in marketing. To integrate and reconcile various findings, a comprehensive measurement of cognitive capital incorporating shared values, shared norms and shared goals is provided for the present study. Moreover, no study has yet examined the impact of cognitive capital on building and sustaining customer satisfaction through employee self-efficacy.

In addition, Ref. [43] conveys that national culture is likely to affect organisational culture; as a result, the latter "would logically be expected to affect the behaviour of the entire organisation" [43]. Furthermore, Ref. [44] observes that organisational culture cannot be divorced from individuals' behaviours such as employees, managers, and customers. Hence, shared values and norms have as much influence on organizational culture and innovating capabilities [45-48]. Since these values, norms, and principles facilitate cognitive capital and act as a basis for conducting business services' transactions in order to ensure that cognitive capital dimensions (shared value, norms, and goals) affect positively employees' self-efficacy that in turn sustain customer satisfaction. However, the recognition of social shared values and norms as the basis of employee self-efficacy and sustaining customer satisfaction has not been well examined. Appendix A briefly recapitulates some key studies related to the aforementioned constructs.

Despite ever-increasing interest in the development of cognitive capital, employee self-efficacy, and building and sustaining customer satisfaction concepts, these studies are disconnected, and numerous important empirical questions remain under-explored. Hence, this study investigates the effect of cognitive capital dimensions on building and sustaining customer satisfaction in the long term through the mediating role of employee self-efficacy in the Egyptian tourism context (category A travel agents and five- and four-star hotels). The study by United Nations World Tourism Organization (UNWTO) [49] classified Egypt as the world's most hastily rising destination in terms of the inbound percentage growth in tourists (55.1\%). This rise shows the insistence and permanence of several hospitality enterprises. The Egyptian tourism sector is asserting itself as the engine of Egypt's economic development. Despite this level of importance, there is a shortage of tourism-related studies that integrate the latter constructs into a theoretical framework. Therefore, this paper aims to investigate 
the role of cognitive capital in building and sustaining customer satisfaction through enhancing employees' self-efficacy.

The remainder of this paper is organised as follows. The Section 2 sets up the theoretical conceptualisation and the development of hypotheses. This paper advances our understanding of the effect of cognitive capital dimensions on sustaining customer satisfaction through the mediating roles of employee self-efficacy. Section 3 explains the methodological approach (e.g., constructs measurement, items' operationalisation, data sources, and, the use of structural equation modelling (SEM) for data analysis. Section 4 presents and discusses findings. Our considered key dimensions of cognitive capital (i.e., shared norms, shared values, and shared goals) enhance employee efficacy which subsequently leads to sustained customer satisfaction. Our structural equation modelling techniques' findings shed light on the impact of intra-firm social interactions on customer experience in the tourism sector. Finally, we discuss the main contributions and directions for future research.

\section{Theoretical Background}

We build on prior studies, such as [35,50-54], which argue that cognitive capital deals with shared norms, shared values, shared representation, and shared goals which enable employees to have a commonly shared practice and create social networks to support their self-efficacy. This debate focuses on the premise that cognitive capital enables social networks to leverage internal and external knowledge that flows within organisational close-knit groups but not on "knowledge" itself as cognition. A theory of collective actions and social capital concepts particularly is characterised by shared history, frequent interactions, and closed structures [35] that may enhance service employee performance $[54,55]$. This relationship between cognitive capital and employee self-efficacy remains unaddressed in the literature.

\section{Cognitive Capital}

Nahapiet \& Ghoshal [35] were among the first scholars who paid attention to and labeled cognitive capital as one of the three dimensions of social capital. Cognitive capital defines as resources providing network members with shared representations, understandings, and systems of meaning [34,40,52,56-59]. This dimension of social capital has received the least attention amongst social capital dimensions in the literature [35,60]. Consistent with this viewpoint, Ref. [34] recently mentioned that there is a shortage of studies that focus on cognitive capital. However, some studies have embarked on defining cognitive capital and outlining key dimensions of cognitive capital. For instance, cognitive capital is defined as the "ability of individuals to create understandings of network behaviour and the aspects involved in the joint learning process" [61]. As demonstrated by [23] cognitive capital puts forward the shared norms that govern how employees behave, think, make judgments, and coordinate their actions. Ref. [62] revealed that cognitive capital includes shared language, codes, and narratives. Cognitive capital is affected by three elements: Similarity in perceptions, common goals, and the way of interaction among network members [58].

Cognitive capital, which enables coordination within an organisation, is derived from shared norms, values, and ways of doing things [34,35]. The hypothetical foundations for the factors (resources) that constitute cognitive capital can be derived from the perspective of social cognitive theory, social exchange theory, and social capital theory [63-67]. Thus, this paper adopts the viewpoint that considers shared values, shared norms, and shared goals as the main dimensions of cognitive capital.

Cognitive capital is one dimension of social capital that attracts scholars from psychology, organisation behaviour, and management discipline $[68,69]$. Cognitive social capital (shared values, norms, and goals) should be widely shared by members inside the organizational to generate united goal alignment and mutual working memory, enhance reciprocity and trust, advance access to various resources and information, and act as a source of possible dynamic competencies and capabilities that can be a source of open innovation [70]. Open Innovation initiates from the acquisition of new knowledge for overcoming operations or design problems [52]. However, if the organizations' 
departments do not have cognitive social capital, the spreading of this knowledge from one department to another is delayed [71]. Cognitive social capital not only delivers a good channel to disseminate knowledge and information but also supports and promotes employees' innovative behavior [71-73]. By increasing the opportunities for key information and know-how methods to be verified and attained by those who require it $[72,74,75]$, service organisations (i.e., hotels, and travel agents) can restructure these resources to create new ideas or options for implementing tasks [76]. Therefore, cognitive social capital can be considered as the cradle of innovation, and it permits valuable know-how methods and key knowledge to easily and freely flow within the organization and enable employees to create completely new services or options [52] to sustain customer satisfaction.

The concept of cognitive social capital is arguably one of the most successful theoretical exports from sociology to other social sciences and to public discourse in the last two decades. It has attracted considerable attention in the academic and practitioner arena [34,37,40-42,77]. However, it remains underexplored in the services marketing literature. Consequently, there is a limited series of studies related to cognitive capital in the services sector, particularly in the tourism sector in the Egyptian context. Hence, this study explores the magnitude of cognitive social capital (shared values, norms, and goals) in the Egyptian tourism industry.

\subsection{Shared Values}

Values play an essential role in building social relationships among employees within an organisation $[29,78]$. They work as a guide to human behaviour and to the decision-making process in achieving organisational goals $[79,80]$. Shared values increase cooperative activities among employees [81]. Shared values also play an important role in identifying, forming, and modifying the nature of relationships between employees within an organisation [82-85]. As reported by [86] that common values between service employees and their managers enhance the service quality outcomes, consequently, sustain customer satisfaction.

Furthermore, shared values between employees enhance their interactions and help them to achieve their common goals [87]. For instance, employees who share the collectivist culture such as Middle East region (e.g., Egypt) accept their collective goals and societal norms more easily [20,85,88-90]. Organisational values, which are derived from employees' values, have positive impact on employees' successful achievement [91,92]. Despite this important role of shared values among employees in encouraging them towards more interaction and cooperation, the tourism scholars have not fully explored the link between shared values and employee self-efficacy.

According to Ref. [93] shared values are associated with feelings of personal success, awareness in understanding personal and organisational values, and achieving organisational goals. Ref. [94] point out that shared values reproduce employees' common "beliefs" "about what is important and what is not". Ref. [95] also reports that shared values reflect the beliefs that employees come to share. These beliefs represent proper standards of conduct or desired results [96]. Accordingly, these standards have strong effects on employees' responses and commitment to personal and organisational goals [93]. As mentioned by [97] that common values create psychological bonds between employees which in turn create unique behaviour standards and work rules within an organisation. Moreover, shared values contribute in developing employees' norms that reflect the expectations of employees' behaviour $[85,98]$.

Shared values among employees shape organisational values [99] and create mutual support among employees $[100,101]$. Shared values in the current study are operationalised in terms of common work values $[20,102-104]$, common beliefs $[95,96,105,106]$ and common attitudes among employees [107] that facilitate establishing common goals within an organisation [81,93,97,100].

Furthermore, common values among employees result in built-up shared goals over time [108]. They improve their practices within an organisation by increasing the degree of responsiveness among themselves, which supports achieving organisational goals [17,93]. In addition, organisational values, which are derived from employees' values, have a positive impact on employees' collective goals [91,92]. Shared values achieve cross-functional team effectiveness [109-111] and improve the competencies 
of employees, which in turn supports a high-quality task performance, and improves operations' effectiveness [112]. A high-quality task performance enhances and strengthens relationships with customers and sustain customer satisfaction [113]. Moreover, joint values among employees support coordination between departments that improve internal organisational processes, enhance employees' efficacies, and supports customer services [52,114-117]. Thus, we propose the following hypotheses (see Figure 1):

Hypothesis (H1). Shared values affect shared norms.

Hypothesis (H2). Shared values affect shared goals.

Hypothesis (H3). Shared values affect employee efficacy.

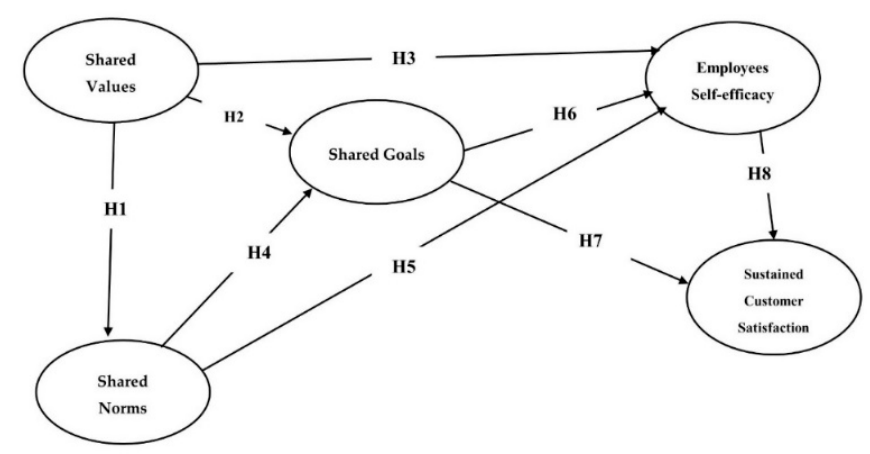

Figure 1. Research framework and hypotheses.

\subsection{Shared Norms}

Many scholars report that shared norms are considered as one of the key elements of cognitive capital $[35,40,48,51,68,118,119]$. Norms act as a control system within an organisation [120] that guides employees' behaviour towards enhancing the organisation's internal functions [121]. Within an organisation shared norms create common obligatory behaviour among employees [18,122]. This common obligatory behaviour enhances the organisation's ability to adapt to environmental changes, enhance employees' willingness to share information and expertise, improves interfirm relationships, and helps to achieve collective goals [123,124]. Despite the important role of shared norms in establishing social capital, there is some ambiguity towards their role in forming cognitive capital [68].

Social norms present the main source of ethical decision-making in an organisation [125]. For example, Ref. [126] asserts that common norms create joint behaviours and obligations between employees. They also encourage employees to respect and show commitment to an organisation's obligatory system. The organisation's obligatory system is affected by organisational ethics and corporate social responsibility [127-129]. The literature overlooked this dimensional angle of cognitive capital.

Organisational ethics describes desired ethical standards and business practices that an organisation adopts [21,130]. Employees' obligations are defined as the ethical duties of each employee toward his/her company [131]. For instance, a common moral obligation among employees enables an ethical climate within an organisation [132,133]. This obligation may be based on professional standards [132,133] and religious principles. The authors of [134] defined an organisation's ethical climate as "the shared perceptions of what is ethically correct behavior and how ethical issues should be handled".

Furthermore, Ref. [21] revealed that "a natural extension of organizational ethics is a company's involvement in corporate social responsibility (CSR)". For example, Ref. [128] regards CSR as "societal 
expectations of corporate behaviour that appear to further some social good, beyond the interests of the firm and that which is required by law". As Egyptian business laws are intertwined with professional regulations, it is vital to establish how shared norms build up social responsibility and shared behaviours among employees which support organisation practices towards achieving organisational goals. These collective norms can create corporate behaviours among employees that reflect a high degree of congruence among employees' social norms $[135,136]$. Subsequently, they may have direct impact on employees' responses to work [21].

Studies of Ref. [94] stressed that having common norms enable employees to improve their self-efficacies. Additionally, Ref. [37] convey that shared norms make employees focus their efforts in a common direction to achieve an organisation's collective goals. Communal norms produce "propositional attitudes" that may affect employees' behaviours [23] They also create obligations within an organisation and encourage employees to share their best practices [131]. They impose uniformity of behaviour within a certain organisation and shape the employees' sense of obligation toward their organisations' goals [124]. However, to the best of our knowledge, no study has examined the effect of social shared norms and values on employee self-efficacy.

Shared norms also establish common obligatory behaviour (behaviour standards and work rules) within an organisation $[132,133,137]$. This common obligatory behaviour enhances the organisation's ability to adapt to environmental changes, enhance employees' willingness to share information and expertise, improves intrafirm relationships, increase employees' competencies, encourage cooperation, inspire social interactions among employees, and helps to achieve collective goals $[51,68,124,131]$. Therefore, shared norms develop cognitive capital among employees. Thus, we suggest the following hypotheses (see Figure 1):

Hypothesis (H4). Shared norms affect shared goals.

Hypothesis (H5). Shared norms affect employee efficacy.

\subsection{Shared Goals}

According to the intra-firm view of cognitive capital, Ref. [41] consider common goals, shared vision, and similar perceptions as the main outcomes of cognitive capital. High levels of cognitive capital provide network members with a common perspective that enables them to perceive and interpret events in similar ways [138]. Several scholars reveal that shared vision is manifested in shared goals $[103,139]$. For example, Ref. [41] use shared vision, which embodies the shared goals to measure cognitive capital. Ref. [140] also notes that shared vision makes employees agree on what are the best goals for them and how they can organise their efforts to solve problems and generate ideas instead of identifying what goals should receive focus. In this paper, we adopt the viewpoint of Merlo et al. [103] who note that "shared vision should be seen principally in terms of agreement on the goals to be achieved, including the fundamental purpose of the organization and not in terms of an agreed view on the means by which the end is realized". Therefore, based on a review of the literature, this study considers shared goals as one of the main dimensions of cognitive capital.

As defined by Chow \& Chan [37] shared goals are "the degree to which one has shared goals, missions, and visions with other people." Ref. [140] introduced a practical definition for shared goals and define it as "the degree of unity principals and agents feel toward common organizational goals". Numerous scholars also note that cognitive capital is more precisely the practice of shared goals among network members $[37,41,42,48,51,77,119,141]$. These communal goals need continuous interactions among network members that help them to understand each other's constraints and opportunities [142,143]. These understandings among organisational departments support each other and help in achieving organisational goals $[144,145]$. As asserted by Refs. [25,146], network members achieve common goals through joint actions. They should possess resources (sharing in interpretations 
and meanings) within a network to make shared actions. While it is to be expected that departments within an organisation will differ in some of their goals, there should be commonality on the goals that are important to the organisation $[141,147,148]$.

The mutual cognition between employees influence observed trusting behaviour among them [149]. Trusting behaviour among employees is basically responsible for improving employees' performance within an organisation [58,70,150,151]. Enhanced employees' performance contributes towards establishing positive customer behaviours such as sustaining customer satisfaction [80,152,153]. Merlo et al. [103] revealed that "the development of a trusting culture is likely to facilitate the propensity of employees to support each other and to cooperate in the pursuit of customer satisfaction". Pervan et al [154] asserted that within organisations a high level of trust among employees is likely to have a positive impact on sustaining successful customer service. Furthermore, Davis et al. [155] found that in-service organisations high levels of trust between managers and service providers sustained customer satisfaction. Shared goals represent one of the key factors in designing a system for inter-organisational coordination [156,157], which help in increasing the willingness of employees to share knowledge and practices [37].

Moreover, shared goals encourage employees to trust their colleagues to provide them with information on unfamiliar issues that will enhance their performance in serving customers [158]. Common cognition among employees also increases their satisfaction [159]. It is affirmed by Liu [160] that in service organisations the integration between front-office and back-office help in redesigning organisation's internal process and support staff in satisfying customer needs. Furthermore, Ref. [159] revealed that the quality of staff (competency) and the quality of internal processes improve customer service and customer satisfaction [161]. In addition, Ref. [162] reports that satisfied employees "perform better and treat customers better, internally and externally, ultimately leading to better overall customer satisfaction". Additionally, Ref. [163] mentioned that organisational service practices have a positive impact on customer satisfaction. The above discussion proves that shared goals among employees enhance customer service and customer satisfaction. Thus, we suggest the following hypotheses:

Hypothesis (H6). Shared goals affect employee efficacy.

Hypothesis (H7). Shared goals affect sustained customer satisfaction.

\section{Employee Self-Efficacy}

Self-efficacy as a concept is not a new term [164]. Employee self-efficacy has gained a lot of attention from different disciplines: Psychology [165-167], human resources management [168-170], information technology [171-174], management field [175,176], tourism arena [167,177,178]. Scholars and practitioners have increasingly explored social capital and its impact on innovation, organisational performance but relationships between cognitive capital and employee self-efficacy remain under-researched in the tourism literature especially in less developed countries (e.g., Egypt). Employee self-efficacy refers to employees' belief in their own capabilities to organize and implement the required responsibilities to obtain the best results [179]. Self-efficacy can as well improve employees' capacity to create and enhance their own resources [180,181] and their ability to produce creative and innovative ideas in the workplace [182,183].

Highly self-efficacious employees are one of the main inimitable resources of differentiation as they support organizations to generate and sustain competitive advantage [184,185]. If self-efficacious service employees demonstrate customer-oriented service, they would not only enhance the level of customer satisfaction but also sustain their satisfaction in long term and encourage reciprocity of information and practices among them [167,186-188]. A high level of employees' self-efficacious increases employees' willingness to serve customers promptly [189]. As shown by Chuang \& Liao [190], "employees' behaviours directly influence customer satisfaction, the level of customer loyalty, and the 
amount of sales". For example, if tourism organizations can go the extra mile to deliver reliable, responsive, courteous, friendly, and helpful service performance; they are likely to enhance their service delivery experience, sustaining customer satisfaction and loyalty [191-197] and profitability [198]. Thus, we posit that:

Hypothesis (H8). Employee efficacy affects sustained customer satisfaction.

\section{Sustained Customer Satisfaction}

Overall sustained customer satisfaction develops over customer experience and is accumulated through service quality and specific service satisfaction [199]. It is determined by the level of interactions between service providers and customers [200,201]. Satisfied customers also support organisation growth, enhance its profitability, and improve its competitive position in the marketplace [202]. It is argued by Reichheld \& Sasser [203] that a 5\% increase in customer satisfaction can produce a profit increase of $25 \%$ to $85 \%$. Moreover, it also reduces costs related to warranties, complaints, defective goods, and failed service costs [9], and increases organisation values [204,205].

Cognitive social capital can be employed by service organisations (i.e., hotels and travel agents) as an open innovation paradigm to sustain customer satisfaction through introducing new services and improve the current ones [52]. There are several challenges and opportunities in service industries due to sever competitive environment, frequently changing customer expectations, their willingness to contribute to service open innovation, with the high demand for customized and personalized types of services [206-208], which can sustain customer satisfaction [209,210].

Furthermore, sustaining customer satisfaction is the major determinant in developing the future relationship between a customer and an organisation [211,212]. It is likely to reduce the risk that the buyer perceives when purchasing a new service [213] the authors of [214] demonstrate that increased customer numbers, increased repeat orders, and reduced customer complaints are the major indicators of customer satisfaction. Despite the positive impact of satisfaction on organisation's position in marketplace, factors such as social shared values and norms which can lead to unsatisfied customers, are often unavoidable due to human and organisational practices. Thus, there is a need to investigate further this phenomenon.

Cognitive capital enables employees to feel more comfortable, which in turn enhances operations' effectiveness and improves relationships with customers [112]. Furthermore, Ref. [20] indicates that cognitive capital enhances social interactions within an organisation that promote joint efforts and create more positive attitudes among them [215]. Positive attitudes among employees increase and sustain customer satisfaction [80,192]. Moreover, the quality of staff (competency) and the quality of internal processes improve customer service such as responding quickly to their customers' needs [159,194,216,217], dealing promptly with customers' complaints [218] and putting a lot of effort into their jobs to satisfy customers' needs [219], which are considered as the main foundations of customer satisfaction [161], Their viewpoint is in line with other scholars [132,133,220,221]. In addition, Ref. [163] mentioned that organisational service practices have a positive impact on customer satisfaction. Deductively, employees who are satisfied with their work have a positive impact on customer satisfaction [162]. However, few studies examine the effect of employee self-efficacy on customer satisfaction in the Egyptian tourism sector.

\section{Methodological Approach}

\subsection{Measures}

In this study, the scales' development was based on the survey of extant theoretical items and a review of the literature. The research instrument under investigation is a series of constructs with items: Shared values $[51,81,103,222]$, shared norms $[105,124]$, shared goals $[81,93,95,100]$, employees 
self-efficacy $[177,190]$ and the perception of sustaining customer satisfaction was derived from Ref. $[112,162]$ and modified to tap the managerial beliefs about the impact of social cognitive on building and sustaining customer satisfaction constructs with their respective items which are modified in the Egyptian context. Appendix B presents the generation of operationalized items.

Building on prior studies' recommendations, we anchor generated items using a five-point Likert-type scale with spectrum $1=$ strongly disagree and $5=$ strongly agree $[3,223]$. The instrument was originally in English. We adopted back-translation method [224]. Three highly qualified Egyptian academic staff translated the instruments from English to Arabic. In addition, another group of two other different Egyptian academic staff made the back translation from Arabic to English. These versions were consistent. We uncovered no differences between the original and translated instruments. To assess translation validity and internal validity, we pre-tested and piloted the questionnaire with five leading academics, four experts, and five managers working in different Egyptian hotels and travel agents' enterprises. Their feedback resulted in several wording changes to the items and the instructions, and deletion of a few items. In addition, the pilot subjects provided positive feedback on the high consistency and face validity of the measures. The final version of the instrument was administrated to 600 top and middle managers working in 165 Egyptian tourism enterprises: 85 hotels ( 250 responses) and 80 travel Agents (240) through drop and collect method [225].

\subsection{Data Collections}

Due to research logistic constraints in developing countries (e.g., Egypt), we used the drop and collect method to deliver and collect to conduct our survey questionnaire in order to improve a high response rate [225]. We obtained 500 responses out of 600 self-administered distributed questionnaires with a response rate of $0.83 \%$. However, 10 cases were discarded because of missing information [226]. Thus, 490 cases were utilised for the analysis purposes. The sample respondents reflect 250 top and middle managers in five- and four-star hotels, and 240 top and middle managers in travel agent category A firms respectively. We received a response from 85 hotels and 80 travel Agents. According to the respondents' experience, $52 \%$ have $7-10$ years' experience; $27 \%$ have more than 10 years of experience and $21 \%$ had less than 7 years of experience. With respect to the respondents' degree, $51.7 \%$ have an undergraduate degree and $48.3 \%$ were postgraduate. The mean values are ranged from 3.92 to 4.22 and the standard deviation scores are between 0.764 and 1.079 which indicate that the data are spread and not focused around its mean.

We also conducted univariate analysis (e.g., independent samples t-test, analysis of one variance: ANOVA) to investigate the non-response bias and responding sample representativeness. The analyses include running these tests; no statistically significant differences at $p$-value of $5 \%$ occur for any attitudinal items in terms of categorical items such as early and late respondents, education level of respondents, respondents' experience, and firm's ownership [227]. Thus, we did not discover any indication of non-response bias in the data. Furthermore, the internal consistency analysis of identified factors yielded overall satisfactory Cronbach Alpha values scores range between 0.80 and 0.95 with inter-item correlations greater than 0.4 [228-230].

\subsection{Confirmatory Factor Analysis}

The appropriateness of the first-order confirmatory factor analysis (CFA) model is assessed through two stages: (1) evaluation of the goodness of model fit of the structural model and (2) evaluate measurement model convergent and discriminant validity. To evaluate the CFA model goodness of fit (GOF), the following threshold values were utilized as advised by Ref. [231,232]: $\chi^{2} / \mathrm{df}$, Root mean square error of approximation (RMSEA), Standardized root mean square residual (SRMR), Normed fit index (NFI), Comparative fit index (CFI), Incremental fit index (IFI), Tucker Lewis Index (TLI), Parsimony normed fit index (PNFI), and Parsimony comparative fit index (PCFI) (see Table 1). A joint confirmatory factor analysis, with all of the variables, was conducted using AMOS v20 to assess the factor structure, reliability, and discriminant validity. The results of the CFA model in Table 1 reveals 
that the measurement model results for reflective measures indicate a satisfactory model fit as all attained fit values met the suggested cut-off scores.

Table 1. Measurement model results for reflective measures.

\begin{tabular}{lcccccccccc}
\hline \multirow{2}{*}{ Model } & \multicolumn{10}{c}{ Obtained Fit Indices } \\
\cline { 2 - 11 } & $\chi^{2} / \mathbf{d f}$ & $p$ & NNFI & RMSEA & SRMR & CFI & RFI & TLI & PNFI & PCFI \\
\hline Overall model fit & 1.69 & 0.00 & 0.93 & 0.06 & 0.032 & 0.94 & 0.90 & 0.95 & 0.84 & 0.79 \\
\hline & \multicolumn{10}{c}{ Suggested fit indices } \\
\hline & $\leq 5$ & $\geq 0.05$ & $\geq 0.90$ & $\leq 0.08$ & $\leq 0.08$ & $\geq 0.90$ & $\geq 0.90$ & $\geq 0.90$ & $\geq 0.05$ & $\geq 0.05$ \\
\hline
\end{tabular}

Moreover, we assure the construct dimensionality by investigating convergent and discriminant validity for each construct. Convergent validity had been assured through three conditions as suggested by Ref. [233]. Firstly, the factor loadings should be significant and exceed 0.5. Secondly, the average variance extracted (AVE) should exceed the cut-off value of 0.5 .

Finally, construct reliability should be higher than 0.7. Table 2 displays a convergent validity evaluation for reflective measures for research constructs. As shown in Table 2 and Figure 2, the three conditions were met which approve convergent validity.

To assess discriminant validity, variables correlation matrix, and the squared root of AVE were employed. The squared root of the average variance extracted (AVE) of every single construct should exceed correlations between any combinations between any two pairs of dimensions in the model as suggested by Fornell et al. [233]. As shown in Table 3 diagonal values (in bold) — the square root of the average variance extracted (AVE) — are higher than off-diagonal values which symbolize the correlations between those dimensions, which approve discriminant validity. Moreover, AVE values of shared values (SV), shared norms (SN), shared goals (SG), employee self-efficacy (ESE) and satisfaction (SAT) (ranged from 0.715 to 0.839 ) are greater than the maximum shared variance values which further confirm discriminant validity [231]. To determine the impact of common method variance, we computed Harmon's one-factor test as suggested by [234]. No single factor accounted for the majority of the covariance ( $43.49 \%$ which is less than $50 \%$ ), suggesting that common method variance is not exclusively responsible for our results. 


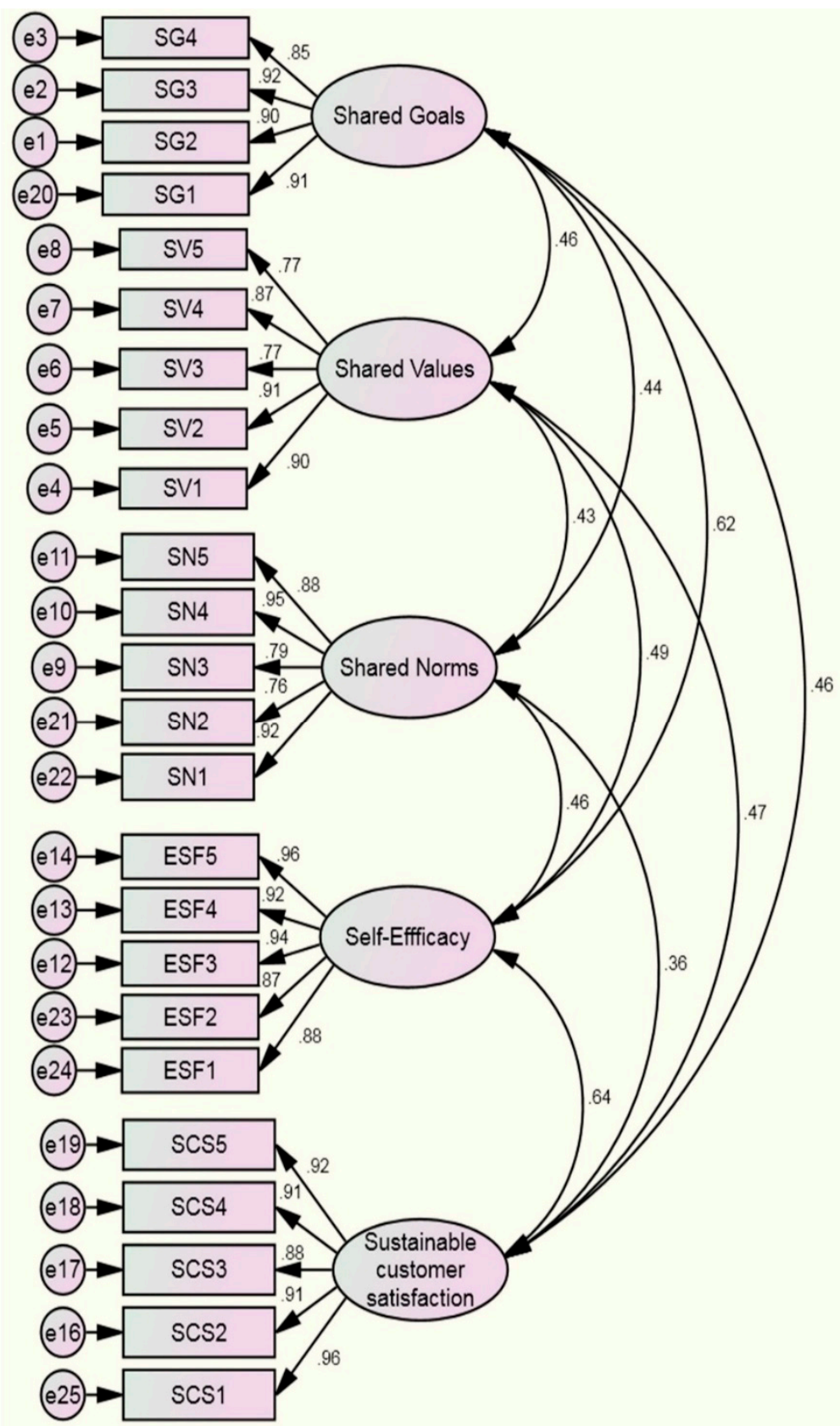

Figure 2. First-order factor analysis. 
Table 2. Measurement CFA model results.

\begin{tabular}{|c|c|c|c|c|c|c|c|c|c|}
\hline Dimensions & $\begin{array}{l}\text { Observed } \\
\text { Variables }\end{array}$ & FL & T-Value & Mean & STD & $a$ & CR & AVE & MSV \\
\hline \multirow{5}{*}{ Shared values } & SV1 & 0.902 & $\mathrm{~b}$ & 4.06 & 0.929 & \multirow{5}{*}{0.927} & \multirow{5}{*}{0.926} & \multirow{5}{*}{0.715} & \multirow{5}{*}{0.244} \\
\hline & SV2 & 0.911 & 31.197 & 4.11 & 0.868 & & & & \\
\hline & SV3 & 0.768 & 22.002 & 4.01 & 1.016 & & & & \\
\hline & SV4 & 0.866 & 27.873 & 4.11 & 0.912 & & & & \\
\hline & SV5 & 0.770 & 22.110 & 3.97 & 1.079 & & & & \\
\hline \multirow{5}{*}{ Shared norms } & SN1 & 0.918 & $\mathrm{~b}$ & 4.20 & 0.934 & \multirow{5}{*}{0.934} & \multirow{5}{*}{0.935} & \multirow{5}{*}{0.743} & \multirow{5}{*}{0.207} \\
\hline & SN2 & 0.763 & 22.532 & 4.21 & 0.917 & & & & \\
\hline & SN3 & 0.792 & 24.196 & 4.29 & 0.798 & & & & \\
\hline & SN4 & 0.947 & 37.579 & 4.13 & 0.993 & & & & \\
\hline & SN5 & 0.876 & 30.378 & 4.08 & 1.077 & & & & \\
\hline \multirow{4}{*}{ Shared goals } & SG1 & 0.912 & $\mathrm{~b}$ & 3.92 & 0.915 & \multirow{4}{*}{0.943} & \multirow{4}{*}{0.943} & \multirow{4}{*}{0.804} & \multirow{4}{*}{0.382} \\
\hline & SG2 & 0.896 & 31.379 & 3.93 & 0.937 & & & & \\
\hline & SG3 & 0.924 & 33.936 & 3.93 & 0.925 & & & & \\
\hline & SG4 & 0.854 & 27.942 & 4.05 & 0.888 & & & & \\
\hline \multirow{5}{*}{ Employees self- efficacy } & ESF1 & 0.877 & $\mathrm{~b}$ & 4.06 & 1.068 & \multirow{5}{*}{0.963} & \multirow{5}{*}{0.962} & \multirow{5}{*}{0.836} & \multirow{5}{*}{0.415} \\
\hline & ESF2 & 0.865 & 27.257 & 4.11 & 1.029 & & & & \\
\hline & EFS3 & 0.938 & 32.793 & 4.06 & 1.075 & & & & \\
\hline & EFS4 & 0.923 & 31.538 & 4.10 & 1.006 & & & & \\
\hline & ESF5 & 0.964 & 35.243 & 4.09 & 1.012 & & & & \\
\hline \multirow{5}{*}{ Sustained Customer satisfaction } & SCS1 & 0.957 & $\mathrm{~b}$ & 4.22 & 0.764 & \multirow{5}{*}{0.962} & \multirow{5}{*}{0.963} & \multirow{5}{*}{0.839} & \multirow{5}{*}{0.415} \\
\hline & SCS2 & 0.913 & 39.792 & 4.11 & 0.806 & & & & \\
\hline & SCS3 & 0.877 & 34.477 & 4.11 & 0.860 & & & & \\
\hline & SCS4 & 0.912 & 39.559 & 4.14 & 0.881 & & & & \\
\hline & SCS5 & 0.920 & 41.038 & 4.14 & 0.855 & & & & \\
\hline
\end{tabular}

Note: FL = factor loading; STD = standard deviation; $a$ = Alpha value; $\mathrm{CR}=$ composite reliability; AVE = average variance extracted; MSV = maximum shared value; $\mathrm{b}$ : fixed to set the scales. 
Table 3. Discriminant validity assessment for research variables.

\begin{tabular}{cccccc}
\hline Variables & SV & SN & SG & ESE & SAT \\
\hline SV & $\mathbf{0 . 9 1 4}$ & & & & \\
SN & 0.618 & $\mathbf{0 . 8 9 7}$ & & & \\
SG & 0.494 & 0.458 & $\mathbf{0 . 8 4 6}$ & & \\
ESE & 0.455 & 0.444 & 0.425 & $\mathbf{0 . 8 6 2}$ & \\
SAT & 0.644 & 0.459 & 0.468 & 0.364 & $\mathbf{0 . 9 1 6}$
\end{tabular}

$\mathrm{SV}=$ shared values, $\mathrm{SN}=$ shared norms, $\mathrm{SG}=$ shared goals, $\mathrm{ESE}=$ employees' self- efficacy, $\mathrm{SAT}=$ satisfaction Diagonal elements (in bold) are the square root of the average variance extracted (AVE). Off-diagonal elements are the correlations among constructs. For discriminant validity, diagonal elements should be larger than off-diagonal elements.

\section{Structural Equations Modelling (SEM) Results}

After establishing confidence in the appropriateness of the measures, we examined the structural model. The structural model examines the relationship between cognitive capital dimensions and sustainable customer satisfaction in the Egyptian tourism industry (hotel and travel agents). We used structural equation modelling to investigate the structural model. The proposed model was examined using the maximum likelihood estimation method with AMOSv20. The fit measures for the structural model showed satisfactory values as shown in Table 4.

Table 4. Assessment of overall model fit.

\begin{tabular}{ccccccccccc}
\hline \multirow{2}{*}{ Model } & \multicolumn{10}{c}{ Obtained Fit Indices } \\
\cline { 2 - 11 } & $\chi^{2} / \mathbf{d f}$ & $p$ & NFI & RMSEA & SRMR & CFI & RFI & TLI & PCFI & PNFI \\
\hline Overall model fit & 1.36 & 0.00 & 0.973 & 0.043 & 0.054 & 0.974 & 0.974 & 0.965 & 0.875 & 0.822 \\
\hline & & & \multicolumn{7}{c}{ Suggested Fit Indices } \\
\hline & $\leq 5$ & $\geq 0.05$ & $\geq 0.90$ & $\leq 0.08$ & $\leq 0.08$ & $\geq 0.90$ & $\geq 0.90$ & $\geq 0.90$ & $\geq 0.50$ & $\geq 0.50$ \\
\hline
\end{tabular}

The results of path analysis for the proposed model of this paper are illustrated in Figure 3 and Table 5.

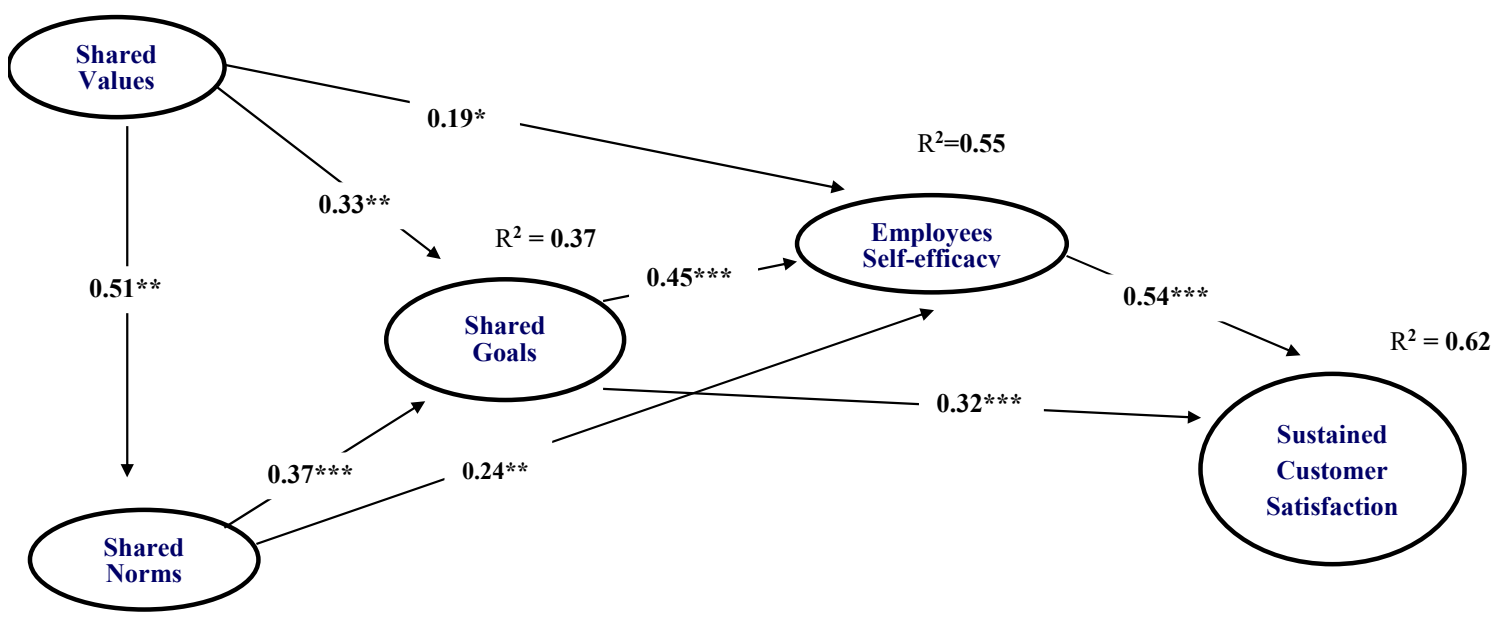

Figure 3. SEM results for the research model. ${ }^{*} p<0.05 ;{ }^{* *} p<0.01 ;{ }^{* *} p<0.001$. 
Table 5. Summary of SEM results for the proposed model.

\begin{tabular}{cccc}
\hline Predictor Variables & $\begin{array}{c}\text { Criterion } \\
\text { Variables }\end{array}$ & $\begin{array}{c}\text { Hypothesised } \\
\text { Relationship }\end{array}$ & $\begin{array}{c}\text { Standardised } \\
\text { Coefficient }\end{array}$ \\
\hline Shared values & Shared norms & $\mathrm{H}_{1} \rightarrow$ Support & $0.51^{* * *}$ \\
\hline Shared values & Shared goals & $\mathrm{H}_{2} \rightarrow$ Support & $0.33^{* * *}$ \\
Shared norms & $\mathrm{H}_{3} \rightarrow$ Support & $0.37^{* * *}$ \\
\hline Shared values & Service employee elf-efficacy & $\mathrm{H}_{4} \rightarrow$ Support & $0.19^{*}$ \\
Shared norms & $\mathrm{H}_{5} \rightarrow$ Support & $0.24^{* *}$ \\
\hline Shared goals & Service employee elf-efficacy & $\mathrm{H}_{6} \rightarrow$ Support & $0.45^{* * *}$ \\
& Sustained Customer satisfaction & $\mathrm{H}_{7} \rightarrow$ Support & $0.32^{* * *}$ \\
\hline Service employee elf-efficacy & Sustained Customer satisfaction & $\mathrm{H}_{8} \rightarrow$ Support & $0.54^{* * *}$ \\
\hline & ${ }^{*} p<0.05 ; * * 0.01 ; * * * 0.001$. & &
\end{tabular}

According to Table 5, our results support the positive significant impact of shared values among employees in their norms $(\beta 1=+0.51$ with $p<0.001)$ which verified H1. Thus, employees who share the same work values, beliefs, and attitudes will adhere to behaviour standards and work rules within an organisation as supported by earlier findings of Ref. [97,98].

Moreover, common employees' values have a significant positive impact on shared goals among them $(\beta 2=+0.33$ with $p<0.001)$ which confirmed H2. So, employees with common values easily accepted collective goals and this result is compatible with the findings of Ref. [81,93,95,97,100]. In the same line, common employees' norms values affect positively on joint goals among them. Thus, H3 ( $\beta 3=+0.37$ with $p<0.001)$ is powerfully confirmed. Therefore, employees who adhere to behaviour standards and work rules within an organisation are more capable of reaching common goals. This result is in agreement with the earlier findings of $[124,137,140]$.

According to our expectation, shared values positively contribute in developing service employee's self-efficacy, and our results actually support $\mathrm{H} 4(\beta 4=+0.19$ with $p>0.05$ and $\beta 5=+0.24$ with $p>0.001)$. According to $\mathrm{H} 4$ employees who share the same work values, beliefs and attitudes have a greater chance of increasing their efficacies as recommended by Refs. [111,112,235]. Moreover, the result of H5 proved that employees who adhere to behaviour standards and work rules within an organisation are more willing to enhance their efficacies as suggested by earlier findings of Refs. [51,124,131]. As hypothesised in (H6), we find a significant and strong positive link between sharing goals among employees and their efficacies within tourism sector in Egypt $(\beta 6=+0.45$ with $p>0.001)$ as the earlier findings of [149-151]. In other words, common understandings toward organisational goals, having a commonality of purpose, having consistent ideas about what an organisation should be trying to achieve, and being enthusiastic about pursuing collective goals and a common vision among employees improve open communication, cooperation, collaboration, social support and exchange of resources (experience and expertise) among employees. Furthermore, our findings confirm a positive relationship between shared goals among employees and sustainable customer satisfaction which verified H7 ( $\beta 7=+0.32$ with $p<0.001)$ as recommended by Ref. [236,237].

Finally, as proposed in $\mathrm{H} 8$ our findings verified the positive and direct impact of service employee's self-efficacy on sustainable customer satisfaction $(\beta 8=+0.54$ with $p<0.001)$ as in the earlier findings of Ref. [103,162].

A supplementary test for mediation assessed the significance of the indirect effects via shared goals and service employee's self-efficacy as shown in Table 6. Our results proved that shared values have a strong indirect impact on shared goals via shared norms among employees. These results prove the impact of an indirect effect of shared values on common goals among employees via shared norms increase the positive total effects from 0.33 to 0.52 ( $\beta$ for indirect impact via shared norms $=+0.19$ while $\beta f$ or direct impact $=+0.33$ ). Moreover, shared values as one of the determinants of cognitive capital has an indirect effect on employees self-efficacy via shared norms \& goals among employees ( $\beta$ for indirect impact via shared norms \& goals $=+0.36$ while $\beta$ for direct impact $=+0.19$ ), which means 
that increasing similarity in work values, common attitudes and common beliefs among employees has a strong indirect impact on service employees self-efficacy through developing an obligation with professional standards and work rules among employees which enhance their abilities in setting common organisation goals. Our results also demonstrate that shared values also have a strong indirect influence on sustaining customer satisfaction via employees' common norms, degree of shared goals among service employees within an organisation, and employees efficacies ( $\beta$ for indirect impact via common norms, shared goals and employees efficacies $=+0.46$ ).

Table 6. Direct, indirect, and total effects among research variables.

\begin{tabular}{ccccc}
\hline Criterion Variable & Predictor Variables & Direct Effect & Indirect Effect & Total Effects \\
\hline \multirow{3}{*}{ Shared values } & Shared goals & 0.33 & 0.19 & 0.52 \\
& Employee's self-efficacy & 0.19 & 0.36 & 0.55 \\
& Sustained customer satisfaction & 0.00 & 0.46 & 0.46 \\
\hline \multirow{2}{*}{ Shared norms } & Employee's self-efficacy & 0.24 & 0.17 & 0.41 \\
& Sustained customer satisfaction & 0.00 & 0.34 & 0.34 \\
\hline Share goals & Sustained customer satisfaction & 0.32 & 0.24 & 0.56 \\
\hline
\end{tabular}

Furthermore, shared norms among employees have a significant indirect influence on employee's self -efficacies via the level of sharing among employees in setting organisational goals ( $\beta$ for indirect impact via shared goals $=+0.17$ whereas $\beta$ for direct impact $=+0.24$ ). This finding demonstrates that the impact of an indirect effect of shared norms on employees' efficacies via common goals among employees increase the positive total effects from 0.24 to 0.41 . In addition, shared norms indirectly affect customer satisfaction through enhancing the process of sharing goals among employees and developing their self-efficacies ( $\beta$ for indirect impact via shared goals \& employee's efficacies $=+0.34$ ). Finally, the degree of employee involvement in setting organisational goals affects both directly and indirectly on customer satisfaction via improving their self-efficacies ( $\beta$ for indirect impact via self-efficacies $=+0.24$ but $\beta$ for direct impact $=+0.32$ ), which means that indirect effect increase the total effects by approximately 43 percent.

\section{Theoretical Implications}

This study contributes to what is currently a limited amount of empirical research on investigating the impact of cognitive capital dimensions on sustainable customer satisfaction via employees' efficacies. It added to contributions of cognitive capital dimensions in customer-employees' relationships in the service industry. Firstly, previous studies drawing upon the social capital theory that have ignored the importance of cultural values based on shared beliefs, attitudes, and work values, while studies in the services marketing have paid less attention to the role of cognitive capital as an antecedent of social cognitive theory (e.g., outcome expectations and self-efficacy). Although both theories are different, yet they are complimentary.

Social capital theory (e.g., cognitive capital) is also limited to address employee self-efficacy. Therefore, we introduce the social capital theory (e.g., cognitive capital: Ref. [35]) to supplement the Social Cognitive Theory (e.g., self-efficacy: Ref. [179]) in order to address this deficiency. Moreover, social cognitive theory (e.g., self-efficacy) is inadequate in addressing what dimensions are within a social capital theory and how they affect employees' going the extra miles and efficacy. Furthermore, the literature remains disconnected and fragmented when dealing with both theoretical concepts: Cognitive capital and employee self-efficacy. Thus, this study holistically brings these concepts and examines direct and indirect relationships between the above constructs.

Previous studies have fully failed to examine any relationship among these three conceptual constructs: Cognitive capital, service employee self-efficacy, and sustainable customer satisfaction. Subsequently, this study makes key contributions: It extends the concept of cognitive capital (social capital theory) to include both cultural values and work rules principles. The ability to 
understand and apply cultural values, work rules, and behavioural principles is likely to improve employee performance, and as a result, sustain customer satisfaction. Second, to the best of our knowledge, this is the first study that completely and holistically integrates these three dimensions. This paper contributes to an overall theoretical understanding of the nature and the importance of the facets of cognitive capital as an independent variable and sustainable customer satisfaction and service employee self-efficacy that are respectively dependent and mediating variables.

\section{Managerial Implications}

To foster cognitive capital in organisations, our framework suggests that managers need to do more than merely encourage social interactions among employees. Organisations should also focus on establishing common goals among employees within organisations through developing shared values and norms among employees.

Our results highlight the role of the individual representative (service providers) in business services. The results suggest that representatives who build strong, long-term personal bonds with their colleagues within an organisation will also be supporting the creation of more relational types of exchange with their customers. Therefore, our results may help researchers to refine their understanding of service relationships by introducing a new level of analysis and new explanatory variables. It may also help managers to develop effective and trusting relationships among employees by helping them to coordinate their efforts at both the organisational and personal levels. The development of cognitive capital within an organisation may allow employees to be more efficacious. As a result, the magnitude of customer satisfaction is likely to be sustained. Hence, common values and norms have a major indirect influence on sustainable customer satisfaction. Managers need to constantly maintain and develop social interaction among employees. Moreover, managers should work with their employees to create a positive business environment that is characterised by encouraging teamwork, availability of information about work rules especially for new employees, and motivating employees to adopt a customer focus strategy. This paper informs practice by the recognition of how the benefits of intangible resources accrue to tourism business. This study validated the direct effect of intrafirm cognitive capital on sustaining customer satisfaction within the tourism industry in Egypt. The implication of this is that managers would have an understanding that appropriate cognitive capital strategies can develop effective service employees' performance. As suggested by the cognitive capital theory, an organisation's unique cognitive capital resources and capabilities provide the basis for competitive advantage. Therefore, managers should recognise the importance of cognitive capital dimensions in the development of social capital within the organisation. Finally, hotels and travel agents that are characterized by high customer contact and intensive labor usage, should regard cognitive social capital as a type of resource that can be employed not only to develop new services but also to enhance the current services in order to sustain customer satisfaction. Cognitive social capital can deliver different and helpful information and knowledge for hotels and travel agents to design and develop new services that fulfill the continuously changing customer requirement. For example, middle managers in hotels and travel agents should pay great attention to customers' requirements and preferences and report these requirements to top managers to adjust the design of the services accordingly to sustain customer satisfaction.

\section{Limitations and Further Research Areas}

This study is restricted by some limitations. A long-term research would deliver more significant support for the results of the current study. Moreover, as Nahapiet \& Ghoshal [35] reveals, cognitive capital is a continuously changing process. Thus, we suggest that the study can be replicated by employing in-depth interviews. Additional potential constraint of this study is its context (the tourism sector). Accordingly, the results might be different context, (e.g., banks, retailers, etc.). Further studies should also explore the effect of interfirm cognitive capital on the relationship between business partners such as supply chain. Several studies investigate the role of interfirm social capital, relational 
capital, and even structural capital on improving the performance of supply chain whereas there is a shortage in the studies that examine the role of cognitive capital in increasing supply chain effectiveness.

Author Contributions: Conceptualization, E.M., R.A., and I.A.E.; methodology, A.M.S.A., I.A.E., and M.A.A.; software, I.A.E.; validation, E.M., and I.A.E.; formal analysis, A.M.S.A.; investigation E.M.; resources, M.A.A.; data curation, A.M.S.A.; writing-original draft preparation, E.M., R.A., A.M.S.A., and I.A.E.; writing一review and editing, A.M.S.A., E.M., R.A., and I.A.E.; visualization, R.A.; supervision, A.M.S.A.; project administration, I.A.E.; funding acquisition, M.A.A. All authors have read and agreed to the published version of the manuscript.

Funding: The authors extend their appreciation to the Deputyship for Research \& Innovation, Ministry of "Education" in Saudi Arabia for funding this research work through the project number (IFT20178).

Conflicts of Interest: The authors declare no conflict of interest. 


\section{Appendix A}

Table A1. Key Studies Related to this Study's Constructs.

\begin{tabular}{|c|c|c|c|c|}
\hline Shared Values & Shared Norms & Shared Goals & Service Employee Self-Efficacy & Building/Sustaining Customer Satisfaction \\
\hline Rokeach (1973) & Ravlin \& Meglino, (1987) & Tsai \& Ghoshal (1998) & Bandura (1977) & Heskett et al. (2003) \\
\hline Ouchi (1981) & O’Reilly et al. (1991) & Liao \& Welsch (2003) & Bandura (1989) & Malik et al. (2020) \\
\hline Meglino et al. (1989) & McAdams (1997) & Inken \&Tsang (2005) & Khan et al. (2020) & Liu $(2007)$ \\
\hline Nystrom (1990) & Nahapiet \& Ghoshal (1998) & Liao \& Welsch (2005) & Pfeffer (1994) & Peccei \& Rosenthal (1997) \\
\hline Weick and Roberts (1993) & Adams et al. (2001) & McLean (2005) & Heskett, et al. (2003) & Bardy \& Cronin (2001) \\
\hline Kim et al., (2019) & Alder \& Kwon (2002) & Yeşil \& Doğan (2019) & Judeh, \& Abou-Moghli (2019) & Jarvis et al., (2003) \\
\hline King \& Burgess (2008) & Inkpen \&Tseng (2005) & Villena et al. (2010) & Kankanhalli et al. (2005) & Verhoef (2003) \\
\hline Nahapiet \& Ghoshal (1998) & Chow \& Chan (2008) & Merlo et al. (2006) & Karatepe et al. (2006) & Anderson et al. (2004) \\
\hline Chua (2002) & Durlauf \& Blume (2008) & Krause et al. (2007) & Mingyue et al. (2020) & Chen \& Quester (2009) \\
\hline Yeşil, \& Doğan (2019) & Brown \& Trevino (2009) & Presutti et al. (2007) & Yang et al. (2008) & Mithas et al. (2005) \\
\hline Jayachandran et al. (2005) & Deshpande \& Joseph (2009) & Chow and Chan (2008) & Yi \& Gong (2008) & Merlo et al. (2006) \\
\hline Sagnak (2005) & Ramasamy \& Yeung (2009) & Lee (2008) & Chuang \& Liao (2010) & Mustelier et al. (2019) \\
\hline Schunk et al. (2020) & Schunk et al. (2020) & Schunk et al. (2020) & Bayraktar \& Jiménez (2020) & Yun \& Hanson (2020) \\
\hline
\end{tabular}

\section{Appendix B. Operationalisation of Items}

Table A2. Cognitive Capital Dimensions.

\section{Shared Goals:}

SG1: Our employees have common understanding for how to achieve organisation goals. Kim et al. (2019); Tsai and Ghoshal (1998); Merlo et al. (2006); Puhakka (2006) SG2: Our departments have a commonality of purpose.

SG3: Our employees are enthusiastic about pursuing the collective goals of the whole organisation.

SG4: Our departments support each other to achieve organisation goals.

Uzzi (1997); Leana and Van Buren (1999); Inkpen and Tsang (2005)

Tsai and Ghoshal (1998); Chow and Chan (2008); Ko et al. (2008)

Skarmeas, Katsikeas \& Schlegelmilch (2002); Oke et al. (2008)

\section{Shared Values:}

SV1: Our employees share common values of maintaining long- term relationship with customers.

SV2: Our employees encourage collectivism work values.

SV3: Our employees use common terms or jargons which our customers understand.

SV4: A 'team spirit' exists among employees.

SV5: Our employees are open- minded and accept different viewpoints and opinions.

Weick and Roberts (1993); Jayachandran et al. (2005)

Ouchi (1981); Kim et al. (2019); Merlo et al. (2006); Taylor (2007)

Nahapiet and Ghoshal (1998); Schunk et al. (2020); King and Burgess (2008)

Kim et al. (2019); Merlo et al. (2006)

Rokeach (1973); Meglino et al. (1989) 
Table A2. Cont.

\section{Shared Norms:}

SN1: Our employees are expected to comply with the law and professional standards in the field.

SN2: Our employees are adhered to follow ethical principles in serving customers.

SN3: Our employees act within the standards and ethical Code of practice defined by the Central Bank and organisation's regulations.

SN4: Our employees are obligated with the organisation's rules.

SN5: The adherence to organisational rules is the most efficient way to do work.

Adams et al. (2001); Deshpande and Joseph (2009).

Ravlin and Meglino (1987); Ramasamy and Yeung (2009)

Aupperle et al. (1985); Ramasamy and Yeung, (2009)

O'Reilly et al. (1991); Brown and Trevino (2009)

Deshpande and Joseph (2008); Sherif et al. (2006).

Table A3. Employees' Self-efficacy.

\begin{tabular}{cc}
\hline ESF1: Our employees have the willingness to serve customers promptly. & Kankanhalli et al. (2005); He et al. (2009) \\
ESF2: Our employees always cooperate to deliver superior service to customers. & Yun \& Hanson (2020) \\
ESF3: Our employees exert extra effort to help customers. & Judeh \& Abou-Moghli (2019); Yi and Gong (2008) \\
ESF4: Our employees can go the extra mile to serve customers. & Heskett et al. (2003); Cronin et al. (2000) \\
ESF5: Our employees can spend extra time to serve customers. & Doney and Cannon (1997); Bergeron et al. (2008) \\
\hline
\end{tabular}

Table A4. Modified perceived sustainable customer satisfaction.

\begin{tabular}{lr}
\hline CS1: Our employees continuously deal promptly with customers' complaints. & Jarvis et al. (2003); Chen and Quester (2009) \\
CS2: Our employees constantly are approachable and easy to contact & Heskett et al. (2003); Cronin et al. (2000) \\
CS3: Our employees (without stopping) put a lot of effort into their jobs to satisfy customers' needs. & Peccei and Rosenthal, (1997); Merlo et al. (2006) \\
CS4: Our employees always respond quickly to our customers' needs. & Bardy and Cronin, (2001); Ofir and Simonsons (2001) \\
CS5: Our employees continuously give customers the appropriate personnel attention. & Yun \& Hanson (2020); Verhoef (2003); Mustelier et al. (2019) \\
\hline
\end{tabular}




\section{References}

1. Anderson, E.W.; Sullivan, M.W. The antecedents and consequences of customer satisfaction for firms. Mark. Sci. 1993, 12, 125-143. [CrossRef]

2. Batt, R. Managing customer services: Human resource practices, quit rates, and sales growth. Acad. Manag. J. 2002, 45, 587-597.

3. Churchill, A.G.; Suprenant, C. An investigation into the determinants of customer satisfaction. J. Mark. Res. 1982, 19, 491-504. [CrossRef]

4. Heskett, J.; Sasser, W.E.; Scblesinger, L. The Service Profit Chain: How Leading Companies Link Profit and Growth to Loyalty, Satisfaction, and Value; Free Press: New York, NY, USA, 1997.

5. Shugan, S.M. Explanations for the growth of services. In Service Quality: New Directions in Theory and Practice; Oliver, L.R., Rust, T.R., Eds.; SAGE Publications: Thousand Oaks, CA, USA, 2012; pp. 223-240.

6. Unger, L.S.; Stearns, J.M.; Lesser, J.A. Sources of consumer satisfaction with retail outlets: Issues and evidence. In Developments in Marketing Science: Proceedings of the Academy of Marketing Science; Rogers, J.C., III, Lamb, C.W., Jr., Eds.; Springer: Cham, Switzerland, 2015; Volume 57, pp. 34-37. [CrossRef]

7. Hayati, S.; Suroso, A.; Suliyanto, S.; Kaukab, M.E. Customer satisfaction as a mediation between micro banking image, customer relationship and customer loyalty. Manag. Sci. Lett. 2020, 10, 2561-2570. [CrossRef]

8. Anderson, E.; Fornell, C.; Rust, R.T. Customer satisfaction, productivity, and profitability: Differences between goods and services. Mark. Sci. 1997, 16, 129-145. [CrossRef]

9. Fornell, C. A national customer satisfaction barometer: The Swedish experience. J. Mark. 1992, 56, 6-21. [CrossRef]

10. Yu, Y.; Haob, J.; Dongc, X.; Khalifa, M. Information A multilevel model for effects of social capital and knowledge sharing in knowledge-intensive work teams. Int. J. Inf. Manag. 2013, 33, 780-790. [CrossRef]

11. Hafsi, M. The effect of religious involvement on work centrality. Psychologia 1987, 30, 258-266.

12. Triandis, H.C.; McCusker, C.; Hui, C.H. Multimethod probes of individualism and collectivism. J. Pers. Soc. Psychol. 1990, 59, 1006-1020. [CrossRef]

13. Cukur, C.S.; De Guzman, M.R.T.; Carlo, G. Religiosity, values, and horizontal and vertical individualism-collectivism: A study of Turkey, the United States, and the Philippines. J. Soc. Psychol. 2004, 144, 613-634. [CrossRef]

14. Bhagat, R.; Mcquaid, S.; Sara, J. Role of subjective culture in organizations: A review and directions for future research. J. Appl. Psychol. 1982, 67, 653-685. [CrossRef]

15. Hofstede, G. Empirical models of cultural differences. In Contemporary Issues in Cross-Cultural Psychology; Swets \& Zeitlinger Publishers: Lisse, The Netherlands, 1991.

16. Ghayad, R. Corporate governance and the global performance of Islamic banks. Humanomics 2008, 24, 207-216. [CrossRef]

17. Johnson, P.; Duberley, J. Anomie and culture management: Reappraising Durkheim. Organization 2011, 18, 563-584. [CrossRef]

18. Schermerhorn, J.R.; Campling, J.; Poole, D.; Wiesner, R. Management: An Asia Pacific Perspective; John Wiley \& Sons: Brisbane, Australia, 2003.

19. Hatzakis, T.; Lycett, M.; Macredie, R.; Martin, V.A. Towards the development of a social capital approach to evaluating change management interventions. Eur. J. Inf. Syst. 2005, 14, 60-74. [CrossRef]

20. Taylor, S. Creating social capital in MNCs: The international human resource management challenge. Hum. Resour. Manag. J. 2007, 17, 336-354. [CrossRef]

21. Valentine, S.; Fleischman, G. Ethics programs, perceived corporate social responsibility and job satisfaction. J. Bus. Ethics 2007, 77, 159-172. [CrossRef]

22. Montazemi, A.R.; Siam, J.J.; Esfahanipour, A. Effect of network relations on the adoption of electronic trading systems. J. Manag. Inf. Syst. 2008, 25, 233-266. [CrossRef]

23. He, W.; Qiao, Q.; Wei, K.-K. Social relationship and its role in knowledge management systems usage. Inf. Manag. 2009, 46, 175-180. [CrossRef]

24. Zhang, Q.; Pan, J.; Jiang, Y.; Feng, T. The impact of green supplier integration on firm performance: The mediating role of social capital accumulation. J. Purch. Supply Manag. 2020, 26, 100579. [CrossRef]

25. Powers, T.L.; Reagan, W.R. Factors influencing successful buyer-seller relationships. J. Bus. Res. 2007, 60, 1234-1242. [CrossRef] 
26. Alam Choudhury, M.; Hussain, M. A paradigm of Islamic money and banking. Int. J. Soc. Econ. 2005, 32, 203-217. [CrossRef]

27. Haniffa, R.M.; Hudaib, M. Exploring the ethical identity of islamic banks via communication in annual reports. J. Bus. Ethics 2007, 76, 97-116. [CrossRef]

28. Rammal, H.G.; Zurbrugg, R. Awareness of Islamic banking products among Muslims: The case of Australia. J. Financial Serv. Mark. 2007, 12, 65-74. [CrossRef]

29. Meek, V.L. Organizational culture: Origins and weaknesses. Organ. Stud. 1988, 9, 453-473. [CrossRef]

30. Nelson, R.E.; Gopalan, S. Do organizational cultures replicate national cultures? Isomorphism, rejection and reciprocal opposition in the corporate values of three countries. Organ. Stud. 2003, 24, 1115-1151. [CrossRef]

31. Özbilgin, M.; Tatli, A.; Mary, Q.; Nord, W.R. Book Review Essay: Understanding Bourdieu's Contribution to Organization and Management Studies. Acad. Manage. Rev. 2005, 30, 855-877. [CrossRef]

32. Ayoun, B.M.; Moreo, P.J. The influence of the cultural dimension of uncertainty avoidance on business strategy development: A cross-national study of hotel managers. Int. J. Hosp. Manag. 2008, 27, 65-75. [CrossRef]

33. Gelderman, C.J.; Semeijn, J.; Mertschuweit, P.P. The impact of social capital and technological uncertainty on strategic performance: The supplier perspective. J. Purch. Supply Manag. 2016, 22, 225-234. [CrossRef]

34. Lee, R. Social capital and business and management: Setting a research agenda. Int. J. Manag. Rev. 2009, 11, 247-273. [CrossRef]

35. Nahapiet, J.; Ghoshal, S. Social capital, intellectual capital and the organizational advantage. Acad. Manage. Rev. 1998, 23, 242-266. [CrossRef]

36. Edelman, L.F.; Bresnan, M.; Newell, S.; Scarborough, H.; Swan, J. The benefits and pitfalls of social capital: Empirical evidence from two organizations in the United Kingdom. Br. J. Manag. 2004, 15, 59-69. [CrossRef]

37. Chow, W.S.; Chan, L.S. Social network, social trust and shared goals in organizational knowledge sharing. Inf. Manag. 2008, 45, 458-465. [CrossRef]

38. Villena, V.H.; Revilla, E.; Choi, T.Y. The dark side of buyer-supplier relationships: A social capital perspective. J. Oper. Manag. 2011, 29, 561-576. [CrossRef]

39. Jayachandran, S.; Sharma, S.; Kaufman, P.; Raman, P. The role of relational information processes and technology use in customer relationship management. J. Mark. 2005, 69, 177-192. [CrossRef]

40. Liao, J.; Welsch, H. Social capital and entrepreneurial growth aspiration: A comparison of technology- and non-technology-based nascent entrepreneurs. J. High Technol. Manag. Res. 2003, 14, 149-170. [CrossRef]

41. Tsai, W.; Ghoshal, S. Social capital and value creation: The role of intra-firm networks. Acad. Manag. J. 1998, 41, 464-476.

42. Chiu, C.-M.; Hsu, M.-H.; Wang, E.T.G. Understanding knowledge sharing in virtual communities: An integration of social capital and social cognitive theories. Decis. Support Syst. 2006, 42, 1872-1888. [CrossRef]

43. Hofstede, G. Cultures Consequences: International Differences in Work-Related Values; Sage: London, UK, 1980.

44. Triandis, H.C. Individualism and Collectivism; Routledge: New York, NY, USA, 2018.

45. Amsa, P. Organizational culture and work group behaviour: An empirical study. J. Manag. Stud. 1986, 23, 347-362. [CrossRef]

46. Kaufman, P.; Jayachandran, S.; Rose, R.L. The role of relational embeddedness in retail buyers' selection of new products. J. Mark. Res. 2006, 43, 580-587. [CrossRef]

47. Beckert, J. How do fields change? The Interrelations of institutions, networks, and cognition in the dynamics of markets. Organ. Stud. 2010, 31, 605-627. [CrossRef]

48. Ganguly, A.; Talukdar, A.; Chatterjee, D. Evaluating the role of social capital, tacit knowledge sharing, knowledge quality and reciprocity in determining innovation capability of an organization. J. Knowl. Manag. 2019, 23, 1105-1135. [CrossRef]

49. World Tourism Organization (WTO). UNWTO Tourism Highlights, 2018th ed.; UNWTO: Madrid, Spain, 2018.

50. Uzzi, B. The Sources and consequences of embeddedness for the economic performance of organizations: The network effect. Am. Sociol. Rev. 1996, 61, 674-698. [CrossRef]

51. Inkpen, A.C.; Tsang, E.W.K. Social capital, networks, and knowledge transfer. Acad. Manag. Rev. 2005, 30, 146-165. [CrossRef]

52. Tang, T.-W. Making innovation happen through building social capital and scanning environment. Int. J. Hosp. Manag. 2016, 56, 56-65. [CrossRef] 
53. Luo, Y.; Ye, Q. Understanding consumers' loyalty to an online outshopping platform: The role of social capital and perceived value. Sustainability 2019, 11, 5371. [CrossRef]

54. Kim, M.; Cichy, R.F.; Zhang, L.; Yu, J. Antecedents of social capital and its impact on satisfaction and Loyalty. J. Hosp. Mark. Manag. 2018, 28, 263-284. [CrossRef]

55. Bennett, J.B.; Lehman, W.E.; Forst, J.K. Change, transfer climate, and customer orientation: A contextual model and analysis of change-driven training. Group Organ. Manag. 1999, 24, 188-216. [CrossRef]

56. Chua, A. The influence of social interaction on knowledge creation. J. Intellect. Cap. 2002, 3, 375-392. [CrossRef]

57. Krause, D.R.; Handfield, R.; Tyler, B.B. The relationships between supplier development, commitment, social capital accumulation and performance improvement. J. Oper. Manag. 2007, 25, 528-545. [CrossRef]

58. Tsai, Y. Effect of social capital and absorptive capability on innovation in internet marketing. Int. J. Manag. 2006, 23, 157-167.

59. Rodrigo-Alarcón, J.; Parra-Requena, G.; Ruiz-Ortega, M.J. Cognitive social capital and absorptive capacity as antecedents of entrepreneurial orientation: A configurational approach. Eurasian Bus. Rev. 2020, 10, 493-517. [CrossRef]

60. Maurer, I.; Bartsch, V.; Ebers, M. The value of intra-organizational social capital: How it fosters knowledge transfer, innovation performance, and growth. Organ. Stud. 2011, 32, 157-185. [CrossRef]

61. Butler, B.; Purchase, S. Use of social capital among Russian managers of a new generation. Ind. Mark. Manag. 2008, 37, 531-538. [CrossRef]

62. Huang, Q.; Davison, R.M.; Gu, J. Impact of personal and cultural factors on knowledge sharing in China. Asia Pac. J. Manag. 2008, 25, 451-471. [CrossRef]

63. Bandura, A. Human agency in social cognitive theory. Am. Psychol. 1989, 44, 1175-1184. [CrossRef]

64. Mondal, A.H. Social capital formation: The role of NGO rural development programs in Bangladesh. Policy Sci. 2000, 33, 459-475. [CrossRef]

65. Onyx, J.; Bullen, P. Sources of social capital. In Social Capital and Public Policy in Australia; Winter, I., Ed.; Australian Institute of Family Studies: Melbourne, Australia, 2000; pp. 105-135.

66. Dakhli, M.; De Clercq, D. Human capital, social capital, and innovation: A multi-country study. Entrep. Reg. Dev. 2004, 16, 107-128. [CrossRef]

67. Schunk, D.H.; DiBenedetto, M.K. Motivation and social cognitive theory. Contemp. Educ. Psychol. 2020, 60, 101832. [CrossRef]

68. Adler, P.; Kwon, S. Social capital: Prospects for a new concept. Acad. Manag. Rev. 2002, 27, 17-40. [CrossRef]

69. Cooke, P. Social capital, embeddedness, and market interactions: An analysis of firm performance in UK regions. Rev. Soc. Econ. 2007, 65, 79-106. [CrossRef]

70. Leana, C.R.; Van Buren, H.J. Organizational social capital and employment practices. Acad. Manag. Rev. 1999, 24, 538-555. [CrossRef]

71. Nieves, J.; Quintana, A.; Osorio, J. Knowledge-based resources and innovation in the hotel industry. Int. J. Hosp. Manag. 2014, 38, 65-73. [CrossRef]

72. Enz, C.A.; Siguaw, J.A. Revisiting the best of the best: Innovations in hotel practice. Cornell Hosp. Q. 2003, 44, 115. [CrossRef]

73. Yeşil, S.; Doğan, I. Exploring the relationship between social capital, innovation capability and innovation. Innovation 2019, 21, 506-532. [CrossRef]

74. Subramaniam, M.; Youndt, M.A. The influence of intellectual capital on the types of innovative capabilities. Acad. Manag. J. 2005, 48, 450-463. [CrossRef]

75. Edelbroek, R.; Peters, P.; Blomme, R.J. Engaging in open innovation: The mediating role of work engagement in the relationship between transformational and transactional leadership and the quality of the open innovation process as perceived by employees. J. Gen. Manag. 2019, 45, 5-17. [CrossRef]

76. Tang, T.-W.; Wang, M.C.-H.; Tang, Y.-Y. Developing service innovation capability in the hotel industry. Serv. Bus. 2013, 9, 97-113. [CrossRef]

77. Vainio, S. Exchange and combination of knowledge-based resources in network relationship: A study of software firms in Finland. Eur. J. Market. 2005, 39, 1078-1222. [CrossRef]

78. Kenter, J.O. Editorial: Shared, plural and cultural values. Ecosyst. Serv. 2016, 21, 175-183. [CrossRef]

79. Rokeach, M. The Nature of Human Values; The Free Press: New York, NY, USA, 1973. 
80. Bourne, H.; Jenkins, M. Organizational values: A dynamic perspective. Organ. Stud. 2013, 34, 495-514. [CrossRef]

81. Meglino, B.; Ravlin, E.; Adkins, C. A work values approach to corporate culture: A field test of the value congruence process and its relationship to individual outcomes. J. Appl. Psychol. 1989, 74, 424-432. [CrossRef]

82. Schneider, S.C. Strategy formulation: The impact of national culture. Organ. Stud. 1989, 10, 149-168. [CrossRef]

83. Agle, B.R.; Caldwell, C.B. Understanding research on values in business. Bus. Soc. 1999, 38, 326-387. [CrossRef]

84. Gertsen, M.C.; Zølner, M. Recontextualization of the corporate values of a Danish MNC in a subsidiary in Bangalore. Group Organ. Manag. 2012, 37, 101-132. [CrossRef]

85. Huang, C.-E.; Liu, C.-H. Impacts of social capital and knowledge acquisition on service innovation: An integrated empirical analysis of the role of shared values. J. Hosp. Mark. Manag. 2018, 28, 645-664. [CrossRef]

86. Mittins, M.; Abratt, R.; Christie, P. Storytelling in reputation management: The case of Nashua Mobile South Africa. Manag. Decis. 2011, 49, 405-421. [CrossRef]

87. Values and value-orientations in the theory of action: An exploration in definition and classification. In Toward a General Theory of Action; Harvard University Press: Cambridge, MA, USA, 1951; pp. 388-433.

88. Ouchi, W. Theory Z: How American Business can Meet the Japanese Challenge; Addison-Wesley: Boston, MA, USA, 1981.

89. Peterson, M.F.; Ruiz-Quintanilla, S.A. Cultural socialization as a source of intrinsic work motivation. Group Organ. Manag. 2003, 28, 188-216. [CrossRef]

90. Hyder, A.S.; Fregidou-Malama, M. Services marketing in a cross-cultural environment: The case of Egypt. J. Serv. Mark. 2009, 23, 261-271. [CrossRef]

91. Ruppel, C.P.; Harrington, S.J. Sharing knowledge through intranets: A study of organizational culture and intranet implementation. IEEE Trans. Dependable Secur. Comput. 2001, 44, 37-52. [CrossRef]

92. Lai, M.-F.; Lee, G.-G. Risk-avoiding cultures toward achievement of knowledge sharing. Bus. Process. Manag. J. 2007, 13, 522-537. [CrossRef]

93. Posner, B.Z.; Kouzes, J.M.; Schmidt, W.H. Shared values make a difference: An empirical test of corporate culture. Hum. Resour. Manag. 1985, 24, 293-309. [CrossRef]

94. Nahavandi, A.; Malekzadeh, A. Organizational Behavior: The Person-Organization Fit; Prentice Hall: Upper Saddle River, NJ, USA, 1999.

95. Sagnak, M. The value congruence levels of principals and teachers at primary schools. Educ. Theory Pract. 2005, 5, 221-228.

96. Nystrom, P.C. Differences in moral values between corporations. J. Bus. Ethics 1990, 9, 971-979. [CrossRef]

97. Hyde, P.; Williamson, B. The importance of organisational values. Part 1: Is your organisation value congruent? Focus Chang. Manag. 2000, 66, 14-18.

98. Eng, T.-Y. An investigation into the mediating role of cross-functional coordination on the linkage between organizational norms and SCM performance. Ind. Mark. Manag. 2006, 35, 762-773. [CrossRef]

99. Wiener, Y. Forms of value systems: A focus on organizational effectiveness and cultural change and maintenance. Acad. Manag. Rev. 1988, 13, 534-545. [CrossRef]

100. McDonald, P.; Gandz, J. Getting value from shared values. Organ. Dyn. 1992, 20, 64-77. [CrossRef]

101. Stelzl, M.; Seligman, C. Multiplicity across cultures: Multiple national identities and multiple value systems. Organ. Stud. 2009, 30, 959-973. [CrossRef]

102. Hofstede, G. Culture's Consequences: International Differences in Work-Related Values; Sage: London, UK, 1984; Volume 5.

103. Merlo, O.; Bell, S.J.; Mengüç, B.; Whitwell, G.J. Social capital, customer service orientation and creativity in retail stores. J. Bus. Res. 2006, 59, 1214-1221. [CrossRef]

104. Brown, M.E.; Treviño, L.K. Leader-follower values congruence: Are socialized charismatic leaders better able to achieve it? J. Appl. Psychol. 2009, 94, 478-490. [CrossRef]

105. Adkins, C.L.; Ravlin, E.C.; Meglino, B.M. Value congruence between co-workers and its relationship to work outcomes. Group Organ. Manag. 1996, 21, 439-460. [CrossRef] 
106. Jung, D.I.; Sosik, J.J. Group potency and collective efficacy examining their predictive validity, level of analysis, and effects of performance feedback on future group performance. Group Organ. Manag. 2003, 28, 366-391. [CrossRef]

107. Babajee, R.B.; Seetanah, B.; Nunkoo, R. The determinants of hotel financial performance: An intellectual capital perspective. J. Hosp. Mark. Manag. 2020, 29, 1008-1026. [CrossRef]

108. Rhoades, L.; Eisenberger, R.; Armeli, S. Affective commitment to the organization: The contribution of perceived organizational support. J. Appl. Psychol. 2001, 86, 825-836. [CrossRef]

109. Hargadon, A.; Sutton, R.I. Technology brokering and innovation in a product development firm. Adm. Sci. Q. 1997, 42, 716-749. [CrossRef]

110. Hoegl, M.; Parboteeah, K.P.; Munson, C.L. Team-level antecedents of individuals' knowledge networks * Decis. Sci. 2003, 34, 741-770. [CrossRef]

111. Young, C. Top management teams' social capital in Taiwan: The impact on firm value in an emerging economy. J. Intellect. Cap. 2005, 6, 177-191. [CrossRef]

112. Yang, J.; Wang, J.; Wong, C.W.; Lai, K. Relational stability and alliance performance in supply chainz . Omega 2008, 36, 600-608. [CrossRef]

113. Weick, K.E.; Roberts, K.H. Collective mind in organizations: Heedful interrelating on flight decks. Adm. Sci. Q. 1993, 38, 357-381. [CrossRef]

114. Yli-Renko, H.; Autio, E.; Sapienza, H.J. Social capital, knowledge acquisition, and knowledge exploitation in young technology-based firms. Strat. Manag. J. 2001, 22, 587-613. [CrossRef]

115. Sirmon, D.G.; Hitt, M.A.; Ireland, R.D. Managing firm resources in dynamic environments to create value: Looking inside the black box. Acad. Manag. Rev. 2007, 32, 273-292. [CrossRef]

116. Chen, S.-C.; Quester, P. A value-based perspective of market orientation and customer service. J. Retail. Consum. Serv. 2009, 16, 197-206. [CrossRef]

117. De Clercq, D.; Dimov, D.; Thongpapanl, N. The moderating impact of internal social exchange processes on the entrepreneurial orientation-performance relationship. J. Bus. Ventur. 2010, 25, 87-103. [CrossRef]

118. Huysman, M.; De Wit, D. Practices of managing knowledge sharing: Towards a second wave of knowledge management. Knowl. Process. Manag. 2004, 11, 81-92. [CrossRef]

119. Presutti, M.; Boari, C.; Fratocchi, L. Knowledge acquisition and the foreign development of high-tech start-ups: A social capital approach. Int. Bus. Rev. 2007, 16, 23-46. [CrossRef]

120. Bettenhausen, K.; Munighan, K. The development of intergroup norm and the effect of interpersonal structural challenges. Adm. Sci. Q. 1991, 36, 20-35. [CrossRef]

121. Schultz, K.L.; Juran, D.C.; Boudreau, J.W. The effects of low inventory on the development of productivity norms. Manag. Sci. 1999, 45, 1664-1678. [CrossRef]

122. O'Reilly, C.; Chatman, J.; Caldwell, D. People and organizational culture: A profile comparison approach to assessing person-organization fit. Acad. Manag. J. 1991, 34, 487-516.

123. Hau, Y.S.; Kim, B.; Lee, H.; Kim, Y.G. The effects of individual motivations and social capital on employees' tacit and explicit knowledge sharing intentions. Int. J. Inf. Manag. 2013, 33, 356-366. [CrossRef]

124. Durlauf, S.; Blume, L. Social Norms in New Palgrave Dictionary of Economics, 2nd ed.; Macmillan: London, UK, 2008.

125. Ambrose, M.L.; Arnaud, A.; Schminke, M. Individual moral development and ethical climate: The influence of person-organization fit on job attitudes. J. Bus. Ethics 2007, 77, 323-333. [CrossRef]

126. King, S.F.; Burgess, T.F. Understanding success and failure in customer relationship management. Ind. Mark. Manag. 2008, 37, 421-431. [CrossRef]

127. Logsdon, J.; Yuthas, K. Corporate social performance, stakeholder orientation, and organizational moral development. J. Bus. Ethics 1997, 16, 213-226. [CrossRef]

128. McWilliams, A.; Siegel, D. Corporate social responsibility: A theory of the firm perspective. Acad. Manag. Rev. 2001, 26, 117-127. [CrossRef]

129. Achua, J.K. Corporate social responsibility in Nigerian banking system. Soc. Bus. Rev. 2008, 3, 57-71. [CrossRef]

130. Aupperle, K.E.; Carroll, A.B.; Hatfield, J.D. An empirical examination of the relationship between corporate social responsibility and profitability. Acad. Manag. J. 1985, 28, 446-463.

131. Hoffman, J.J.; Hoelscher, M.L.; Sherif, K. Social capital, knowledge management, and sustained superior performance. J. Knowl. Manag. 2005, 9, 93-100. [CrossRef] 
132. Adams, J.S.; Tashchian, A.; Shore, T.H. Codes of ethics as signals for ethical behavior. J. Bus. Ethics 2001, 29, 199-211. [CrossRef]

133. Deshpande, S.P.; Joseph, J. Impact of emotional intelligence, ethical climate, and behavior of peers on ethical behavior of nurses. J. Bus. Ethics 2008, 85, 403-410. [CrossRef]

134. Victor, B.; Cullen, J. A Theory and Measure of Ethical Climate in Organizations. In Research in Corporate Social Performance and policy; Frederick, W.C., Ed.; JAI Press: Greenwich, UK, 1987.

135. Sethi, S.P. Dimensions of corporate social performance: An analytical framework. Calif. Manag. Rev. 1975, 17, 58-64. [CrossRef]

136. Lindgreen, A.; Swaen, V.; Johnston, W.J. Corporate social responsibility: An empirical investigation of U.S. Organizations. J. Bus. Ethics 2008, 85, 303-323. [CrossRef]

137. McAdams, R.H. The origin, development, and regulation of norms. Mich. Law Rev. 1997, 96, $338-433$. [CrossRef]

138. Boland, R.J.; Tenkasi, R.V. Perspective making and perspective taking in communities of knowing. Organ. Sci. 1995, 6, 350-372. [CrossRef]

139. McLean, L.D. Organizational culture's influence on creativity and innovation: A review of the literature and implications for human resource development. Adv. Dev. Hum. Resour. 2005, 7, 226-246. [CrossRef]

140. Mukherji, A.; Wright, P.; Mukherji, J. Cohesiveness and goals in agency networks: Explaining conflict and cooperation. J. Socio-Econ. 2007, 36, 949-964. [CrossRef]

141. Puhakka, V. Effects of social capital on the opportunity recognition process. J. Enterprising Cult. 2006, 14, 105-124. [CrossRef]

142. Jap, S.D. Pie-expansion efforts: Collaboration processes in buyer-supplier relationships. J. Mark. Res. 1999, 36, 461-475. [CrossRef]

143. Clarke, N. The relationships between network commitment, its antecedents and network performance. Manag. Decis. 2006, 44, 1183-1205. [CrossRef]

144. Ko, K.; Kim, S.; Kim, M.; Woo, J. Organizational characteristics and the CRM adoption process. J. Bus. Res. 2007, 61, 65-74. [CrossRef]

145. Oke, A.; Idiagbon-Oke, M.; Walumbwa, F. The relationship between brokers' influence, strength of ties and NPD project outcomes in innovation-driven horizontal networks. J. Oper. Manag. 2008, 26, 571-589. [CrossRef]

146. Skarmeas, D.; Katsikeas, C.S.; Schlegelmilch, B.B. Drivers of commitment and its impact on performance in cross-cultural buyer-seller relationships: The importer's perspective. J. Int. Bus. Stud. 2002, 33, 757-783. [CrossRef]

147. Anumba, C.; Siemieniuch, C.; Sinclair, M. Supply chain implications of concurrent engineering. Int. J. Phys. Distrib. Logist. Manag. 2000, 30, 566-597. [CrossRef]

148. Samaddar, S.; Nargundkar, S.; Daley, M. Inter-organizational information sharing: The role of supply network configuration and partner goal congruence. Eur. J. Oper. Res. 2006, 174, 744-765. [CrossRef]

149. Fichman, M. Straining towards trust: Some constraints essay on studying trust in organizations. J. Organ. Behav. 2003, 24, 133-157. [CrossRef]

150. Mair, J.; Marti, I. Social entrepreneurship research: A source of explanation, prediction, and delight. J. World Bus. 2006, 41, 36-44. [CrossRef]

151. Lu, Y.; Yang, D. Information exchange in virtual communities under extreme disaster conditions. Decis. Support Syst. 2011, 50, 529-538. [CrossRef]

152. Menon, K.; O'Connor, A. Building customers' affective commitment towards retail banks: The role of CRM in each 'moment of truth'. J. Financ. Serv. Mark. 2007, 12, 157-168. [CrossRef]

153. Leonidou, L.C.; Talias, M.A.; Leonidou, C.N. Exercised power as a driver of trust and commitment in cross-border industrial buyer-seller relationships. Ind. Mark. Manag. 2008, 37, 92-103. [CrossRef]

154. Pervan, S.J.; Bove, L.L.; Johnson, L.W. Reciprocity as a key stabilizing norm of interpersonal marketing relationships: Scale development and validation. Ind. Mark. Manag. 2009, 38, 60-70. [CrossRef]

155. Davis, J.H.; Schoorman, F.D.; Mayer, R.C.; Tan, H.H. The trusted general manager and business unit performance: Empirical evidence of a competitive advantage. Strat. Manag. J. 2000, 21, 563-576. [CrossRef]

156. Whetten, D. Toward a contingency model for designing interorganizational service delivery systems. Organ. Adm. Sci. 1977, 8, 77-96. 
157. Murray, J.Y.; Kotabe, M. Performance implications of strategic fit between alliance attributes and alliance forms. J. Bus. Res. 2005, 58, 1525-1533. [CrossRef]

158. Thieme, R.J. Perspective: The world's top innovation management scholars and their social capital. J. Prod. Innov. Manag. 2007, 24, 214-229. [CrossRef]

159. Ballantyne, D. Internal networks for internal marketing. J. Mark. Manag. 1997, 13, 343-366. [CrossRef]

160. Liu, H. Development of a framework for customer relationship management (CRM) in the banking industry. Int. J. Manag. 2007, 24, 15-32.

161. Donavan, D.; Hocutt, M. Customer evaluation of service employee's customer orientation: Extension and application. J. Qual. Manag. 2001, 6, 293-306. [CrossRef]

162. Eichorn, F. Applying Internal Customer Relationship Management (IntCRM) Principles for Improving Business/IT Integration and Performance. Ph.D. Thesis, The University of Maryland, Washington, MD, USA, 2004.

163. Tornow, W.; Wiley, J. Service quality and management practices: A look at employee attitudes, customer satisfaction, and bottom-line consequences. People Strat. 1991, 14, 105-115.

164. White, R.W. Motivation reconsidered: The concept of competence. Psychol. Rev. 1959, 66, 297-333. [CrossRef]

165. Bandura, A. Self-Efficacy: The Exercise of Control; WH Freeman/Times Books/Henry Holt and Co.: New York, NY, USA, 1997.

166. Stajkovic, A.D.; Luthans, F. Self-efficacy and work-related performance: A meta-analysis. Psychol. Bull. 1998, 124, 240-261. [CrossRef]

167. Khan, N.A.; Khan, A.N.; Moin, M.F.; Pitafi, A.H. A trail of chaos: How psychopathic leadership influence employee satisfaction and turnover intention via self-efficacy in tourism enterprises. J. Leis. Res. 2020, 1-23. [CrossRef]

168. Barling, J.; Beattie, R. Self-efficacy beliefs and sales performance. J. Organ. Behav. Manag. 1983, 5, 41-51. [CrossRef]

169. Roberts, K.J.; Varki, S.; Brodie, R. Measuring the quality of relationships in consumer services: An empirical study. Eur. J. Mark. 2003, 37, 169-196. [CrossRef]

170. Judeh, M.; Abou-Moghli, A.A. Transformational leadership and employee intent to stay: Mediating effect of employee self-efficacy. Int. J. Acad. Res. Bus. Soc. Sci. 2019, 9, 301-314.

171. Peccei, R.; Rosenthal, P. The antecedents of employee commitment to customer service: Evidence from a UK service context. Int. J. Hum. Resour. Manag. 1997, 8, 66-86. [CrossRef]

172. Compeau, D.R.; Higgins, C.A. Computer self-efficacy: Development of a measure and initial test. MIS Q. 1995, 19, 189-211. [CrossRef]

173. Igbaria, M. The effects of self-efficacy on computer usage. Omega 1995, 23, 587-605. [CrossRef]

174. Mingyue, F.; Krampah-Nkoom, A.; Manu, B.D.; Oduro, D. Evaluating the effects of online training on employee self-efficacy. A dilemma from the banking industry in Ghana. J. Arts Humanit. 2020, 9, 1-16.

175. Wood, R.; Bandura, A. Social cognitive theory of organizational management. Acad. Manag. Rev. 1989, 14, 361-384. [CrossRef]

176. Bayraktar, S.; Jiménez, A. Self-efficacy as a resource: A moderated mediation model of transformational leadership, extent of change and reactions to change. J. Organ. Chang. Manag. 2020, 33, 301-317. [CrossRef]

177. Karatepe, O.M.; Uludag, O.; Menevis, I.; Hadzimehmedagic, L.; Baddar, L. The effects of selected individual characteristics on frontline employee performance and job satisfaction. Tour. Manag. 2006, 27, 547-560. [CrossRef]

178. Pappas, N. Marketing strategies, perceived risks, and consumer trust in online buying behaviour. J. Retail. Consum. Serv. 2016, 29, 92-103. [CrossRef]

179. Eccles, J.S.; Wigfield, A. From expectancy-value theory to situated expectancy-value theory: A developmental, social cognitive, and sociocultural perspective on motivation. Contemp. Educ. Psychol. 2020, 61, 101859. [CrossRef]

180. Schaufeli, W.; Bakker, A.B. Job demands, job resources, and their relationship with burnout and engagement: A multi-sample study. J. Organ. Behav. 2004, 25, 293-315. [CrossRef]

181. Shirom, A. Feeling vigorous at work? The construct of vigor and the study of positive affect in organizations. In Research in Occupational Stress and Well-Being: Vol. 3. Emotional and Physiological Processes and Positive Intervention Strategies; Perrewé, P.L., Ganster, D.C., Eds.; Elsevier: Amsterdam, The Netherlands, 2004; pp. 135-164. 
182. Bakker, A.B.; Gierveld, J.H.; Van Rijswijk, K. Success Factors among Female School Principals in Primary Teaching: A Study on Burnout Work Engagement and Performance; Right Management Consultants: Diemen, The Netherlands, 2006.

183. Gong, Y.; Huang, J.-C.; Farh, J.-L. Employee learning orientation, transformational leadership, and employee creativity: The mediating role of employee creative self-efficacy. Acad. Manag. J. 2009, 52, 765-778. [CrossRef]

184. Pfeffer, J. Competitive Advantage through People: Unleashing the Power of the Work Force; Harvard Business School Press: Boston, MA, USA, 1994.

185. Heskett, J.L.; Sasser, W.E.; Schlesinger, L.J. The Value-Profit Chain: Treat Employees like Customers and Customers like Employees; The Free Press: New York, NY, USA, 2003.

186. Shu, L.; Wei, H.; Peng, L. Making the customer orientation of salespeople unsustainable-The moderating effect of emotional exhaustion. Sustainability 2019, 11, 735. [CrossRef]

187. Kumar, A.; Capraro, V.; Perc, M. The evolution of trust and trustworthiness. J. R. Soc. Interface 2020, 17, 20200491. [CrossRef]

188. Wang, D.; Gan, C.; Wu, C.; Wang, D. Ethical leadership and employee voice: Employee self-efficacy and self-impact as mediators. Psychol. Rep. 2015, 116, 751-767. [CrossRef]

189. Kankanhalli, A.; Tan, B.C.Y.; Wei, K.-K. Contributing knowledge to electronic knowledge repositories: An empirical investigation. MIS Q. 2005, 29, 113-143. [CrossRef]

190. Chuang, C.-H.; Liao, H. Strategic human resource management in service context: Taking care of business by taking care of employees and customers. Pers. Psychol. 2010, 63, 153-196. [CrossRef]

191. Alam Malik, S.; Akhtar, F.; Raziq, M.M.; Ahmad, M. Measuring service quality perceptions of customers in the hotel industry of Pakistan. Total. Qual. Manag. Bus. Excel. 2018, 31,1-16. [CrossRef]

192. Yun, W.; Hanson, N. Weathering consumer pricing sensitivity: The importance of customer contact and personalized services in the financial services industry. J. Retail. Consum. Serv. 2020, 55, 102085. [CrossRef]

193. Migge, T.; Kiffin-Petersen, S.A.; Purchase, S. When Western measures meet Eastern perspectives: A prototyping analysis of xinren in buyer-seller relationships. Ind. Mark. Manag. 2020, 91, 129-141. [CrossRef]

194. Iqbal, M.S.; Hassan, M.U.; Habibah, U. Impact of self-service technology (SST) service quality on customer loyalty and behavioral intention: The mediating role of customer satisfaction. Cogent Bus. Manag. 2018, 5, 1423770. [CrossRef]

195. Zopiatis, A.; Constanti, P.; Theocharous, A.L. Job involvement, commitment, satisfaction and turnover: Evidence from hotel employees in Cyprus. Tour. Manag. 2004, 41, 129-140. [CrossRef]

196. Bergeron, J.; Roy, J. Pleasantly surprising clients: A tactic in relationship marketing for building competitive advantage in the financial services sector. Can. J. Adm. Sci. 2008, 25, 171-184. [CrossRef]

197. Yi, Y.; Gong, T. If employees "go the extra mile," do customers reciprocate with similar behavior? Psychol. Mark. 2008, 25, 961-986. [CrossRef]

198. Hall, C.M.; Williams, A.M. Tourism and Innovation; Routledge: New York, NY, USA, 2019.

199. Ndubisi, N.O. A structural equation modelling of the antecedents of relationship quality in the Malaysia banking sector. J. Financial Serv. Mark. 2006, 11, 131-141. [CrossRef]

200. Beck, J.T.; Chapman, K.; Palmatier, R.W. Understanding relationship marketing and loyalty program effectiveness in global markets. J. Int. Mark. 2015, 23, 1-21. [CrossRef]

201. Caceres, R.C.; Paparoidamis, N.G. Service quality, relationship satisfaction, trust, commitment and business-to-business loyalty. Eur. J. Mark. 2007, 41, 836-867. [CrossRef]

202. Jain, R.; Jain, S. Towards relational exchange in services marketing: Insights from hospitality industry. J. Serv. Res. 2006, 5, 140-150.

203. Reichheld, F.F.; Sasser, W.E. Zero defections: Quality comes to services. Harv. Bus. Rev. 1990, 68, $105-111$.

204. Suchánek, P.; Richter, J.; Králová, M. Customer satisfaction, product quality and performance of companies. Rev. Econ. Perspect. 2015, 14, 329-344. [CrossRef]

205. Mithas, S.; Krishnan, M.; Fornell, C. Why do customer relationship management applications affect customer satisfaction? J. Mark. 2005, 69, 201-209. [CrossRef]

206. Elshaer, I. What is the Meaning of Quality? University Library of Munich: Munich, Germany, 2012.

207. Aguirre, E.; Roggeveen, A.L.; Grewal, D.; Wetzels, M. The personalization-privacy paradox: Implications for new media. J. Consum. Mark. 2016, 33, 98-110. [CrossRef] 
208. Hameed, W.U.; Nisar, Q.A.; Wu, H.-C. Relationships between external knowledge, internal innovation, firms' open innovation performance, service innovation and business performance in the Pakistani hotel industry. Int. J. Hosp. Manag. 2021, 92, 102745. [CrossRef]

209. Chandrasekhar, N.; Gupta, S.; Nanda, N. Food delivery services and customer preference: A comparative analysis. J. Foodserv. Bus. Res. 2019, 22, 375-386. [CrossRef]

210. Mustelier-Puig, L.C.; Anjum, A.; Xu, M. Service encounter communication, altruistic value, and customer satisfaction: A study of overseas tourists buying transportation services in Shanghai. J. China Tour. Res. 2018, 15, 149-171. [CrossRef]

211. Flavián, C.; Guinalíu, M. Consumer trust, perceived security and privacy policy. Ind. Manag. Data Syst. 2006, 106, 601-620. [CrossRef]

212. Lages, L.F.; Lancastre, A.; Lages, C. The B2B-RELPERF scale and scorecard: Bringing relationship marketing theory into business-to-business practice. Ind. Mark. Manag. 2008, 37, 686-697. [CrossRef]

213. Boulding, W.; Staelin, R.; Ehret, M.; Johnston, W.J. A customer relationship management roadmap: What is known, potential pitfalls, and where to go. J. Mark. 2005, 69, 155-166. [CrossRef]

214. Rhodes, J.; Lok, P.; Hung, R.Y.-Y.; Fang, S.-C. An integrative model of organizational learning and social capital on effective knowledge transfer and perceived organizational performance. J. Workplace Learn. 2008, 20, 245-258. [CrossRef]

215. Dirks, K.T.; Ferrin, D.L. The role of trust in organizational settings. Organ. Sci. 2001, 12, 450-467. [CrossRef]

216. Bardy, M.; Cronin, J. Customer orientation effects on customer service perceptions and outcome behaviors. J. Serv. Res. 2001, 3, 241-251. [CrossRef]

217. Ofir, C.; Simonson, I. In search of negative customer feedback: The effect of expecting to evaluate on satisfaction evaluations. J. Mark. Res. 2001, 38, 170-182. [CrossRef]

218. Jarvis, C.; MacKenzie, S.; Podsakoff, P. A critical review of construct indicators and measurement model specification in marketing and consumer research. J. Consum. Res. 2003, 30, 199-218. [CrossRef]

219. Teo, S.; Bentley, T.; Nguyen, D. Psychosocial work environment, work engagement, and employee commitment: A moderated, mediation model. Int. J. Hosp. Manag. 2020, 88, 102415. [CrossRef]

220. Hornak, A.M.; Garza Mitchell, R.L. Changing times, complex decisions: Presidential values and decision making. Community Coll. Rev. 2016, 44, 119-134. [CrossRef]

221. Ramasamy, B.; Yeung, M.C.H. Chinese consumers' perception of corporate social responsibility (CSR). J. Bus. Ethics 2008, 88, 119-132. [CrossRef]

222. Wirtz, J.; Jerger, C. Managing service employees: Literature review, expert opinions, and research directions. Serv. Ind. J. 2016, 36, 757-788. [CrossRef]

223. Ladeira, W.J.; Santini, F.D.O.; Araujo, C.F.; Sampaio, C.H. A meta-analysis of the antecedents and consequences of satisfaction in tourism and hospitality. J. Hosp. Mark. Manag. 2016, 25, 975-1009. [CrossRef]

224. Douglas, S.P.; Craig, C.S. Collaborative and iterative translation: An alternative approach to back translation. J. Int. Mark. 2007, 15, 30-43. [CrossRef]

225. Ibeh, K.I.; Brock, J.K.-U. Conducting survey research among organisational populations in developing countries: Can the drop and collect technique make a difference? Int. J. Mark. Res. 2004, 46, 375-383. [CrossRef]

226. Johnson, R.A.; Wichern, D.W. Applied Multivariate Statistical Analysis, 5th ed.; Prentice-Hall: Englewood Cliffs, NJ, USA, 2002.

227. Armstrong, J.S.; Overton, T. Estimating nonresponse bias in mail surveys. J. Mark. Res. 1977, 14, $396-402$. [CrossRef]

228. Qi, F.; Wang, W. Employee involvement, public service motivation, and perceived organizational performance: Testing a new model. Int. Rev. Adm. Sci. 2016, 84, 746-764. [CrossRef]

229. Hundleby, J.D.; Nunnally, J. Psychometric theory. Am. Educ. Res. J. 1968, 5, 431-433. [CrossRef]

230. Clark, L.; Watson, D. Constructing validity: Basic issues in scale development. Psychol. Assess. 1995, 7, 309-319. [CrossRef]

231. Hair, J.; Anderson, R.; Tatham, R.; Black, W. Multivariate Data Analysis; Prentice Hall: Saddle River, NJ, USA, 2014.

232. Kline, R.B. Principles and Practice of Structural Equation Modeling; Guilford publications: New York, NY, USA, 2015. 
233. Fornell, C.; Larcker, D. Evaluating structural equation models with unobservable variables and measurement error. J. Mark. Res. 1981, 18, 39-50. [CrossRef]

234. Podsakoff, P.M.; Organ, D.W. Self-reports in organizational research: Problems and prospects. J. Manag. 1986, 12, 531-544. [CrossRef]

235. Chen, C.J.; Huang, J.W. How organizational climate and structure affect knowledge management-The social interaction perspective. Int. J. Inf. Manage. 2007, 27, 104-118. [CrossRef]

236. Betts, P. Winning over the medical staff. Health Forum J. 2002, 45, $28-31$.

237. Miretzky, D. Parent-teacher perspectives on parent-teacher relationships. Ph.D. Thesis, University of Illinois, Chicago, IL, USA, 2002.

Publisher's Note: MDPI stays neutral with regard to jurisdictional claims in published maps and institutional affiliations.

(C) 2020 by the authors. Licensee MDPI, Basel, Switzerland. This article is an open access article distributed under the terms and conditions of the Creative Commons Attribution (CC BY) license (http://creativecommons.org/licenses/by/4.0/). 